Frontiers: The Interdisciplinary Journal of Study Abroad Volume 32, Issue 2, pp. 34-71

(c) Atsushi Hasegawa \& Chiharu Shima This work is licensed under the Creative Commons Attribution-NonCommercial-

NoDerivatives 4.0 International License.

DOI 10.36366/frontiers.v32i2.467

THE

FORUM

ON EDUCATION

ABROAD

\title{
Differential Social Experiences of International Students in a Residential Hall in Japan
}

\author{
Atsushi Hasegawa ${ }^{1}$ \& Chiharu Shima²
}

\section{Abstract}

The present study examined differential social experiences of international students living in a residential hall called 'Nihongo House' (Japanese language house) at a Japanese university. By conducting social network analysis (SNA), as well as making use of ethnographic data collected through participant observation and semi-structured interviews, we explain how constellations of interpersonal relations at the house transformed over the course of one semester and what factors were responsible for those changes. Additionally, we present three focal cases of international students. These students-with different motivational orientations, personal dispositions and abilities, and social standing-went through diverse social processes, which led to different levels of success in respective accounts. Based on the analysis, we discuss how social experiences of these students in this particular setting can be understood in relation to their language use and potential development and how this type of residential hall can effectively nurture interpersonal relationships.

1 UniVERSiTY OF HAWAII AT MANOA, HONOLULU, USA

2 AKITA INTERNATIONAL UNIVERSITY, AKITA, JAPAN

Corresponding author: Atsushi Hasegawa, University of Hawaii at Manoa, atsushih@hawaii.edu 


\section{Abstract in Japanese}

本研究では、日本の大学における外国人留学生と日本人学生の人間関係構築プロセスを 記述し、言語使用·習得への示唆を考察する。特に、寮という制度的に区切られた空間に 着目し、寮の中で、1）どのように人間関係が構築され、コミュニティが形成されたのか、2) どのような要因が人間関係構築やコミュニティ形成に影響を与えたかを明らかにすることを 目的亡する。対象は日本国内のある大学に近年設置されたテ一マ別寮の一つである「日本 語ハウス」に住む留学生と日本人 14 名である。データとして、学期開始前と終了後に行っ た社会ネットワーク調査、半構造化面接、参与観察、寮に関する文書等を一学期間収集し た。これらのデータを言語社会化の観点から分析した結果、メンバーによる活動の企画や 参加を通したコミュニティ形成の過程が観察された。一方で、個人による参加のプロセスの 違いや、コミュニティ全体としての関係、細分化された個人間での関係といった多層性を持 つた複雑な人間関係の存在が明らかとなった。また、異なる参加のパターンを見せた3名 の留学生のケースを紹介し、彼らの参加プロセスに与えた影響について、言語能力 (日本 語や英語)、各学生の所属する複数のコミュニティ(サークルや授業等)における日本語八 ウスコミュニティの位置づけ、ハウス内外の環境という観点から例証し、生活·学びの環境 づくりについて考察する。

\section{Keywords:}

Socialization, Social network, EMI, Japan, Study abroad, Residence hall

\section{Introduction}

Over the past decade, study abroad (SA)—as a site of language development-has attracted growing attention in second language acquisition (SLA) research, which is evident in recent journal special issues (e.g., Plews \& Jackson, 2017; Wolcott, 2016), as well as monographs and edited volumes dedicated to this topic (e.g., Benson, Barkhuizen, Bodycott, \& Brown, 2013; Hasegawa, 2019; Kinginger, 2013; Sanz \& Morales-Front, 2018; Taguchi, 2015). This growth reflects the steady increase of outbound SA participants from the United States (Institute for International Education, 2017) and across the world (Oxford University, 2017). In contrast to the earlier research that primarily attempted to examine a direct cause-effect relationship between the SA context and linguistic or learner-internal outcomes (e.g., Dewey, 2004; Freed, 1995; Freed, Segalowitz, \& Dewey, 2004; Lafford, 1995), many recent advances have concerned the complex realities in diverse social settings and tried to capture participants' unique experiences in such settings from various angles (Kinginger, 2013). 
Following this line of developments, the present study examined differential social experiences of international students studying Japanese at a Japanese university. The study specifically focused on a social network formed at a residential hall called 'Nihongo House' (Japanese language house) at the university. When it comes to housing arrangements abroad, homestay has traditionally attracted much attention in SA research (e.g., Cook, 2006; Tan \& Kinginger, 2013; Tanaka, 2007; Wilkinson, 2002). However, an increasing number of studies have begun investigating social experiences of residential halls (e.g., Diao, 2014, 2016). Compared with homestay interaction, which often takes place at meal table, peer socialization is presumably more dynamic and variable, which leads to the perceived success or failure of students' SA experience (Hasegawa, 2019). Using a survey instrument developed for investigating social networks (e.g., De Lange, Agneessens, \& Waege, 2004; Romney \& Weller, 1984), as well as the ethnographic data collected through participant observation and semi-structured interviews, this study aims to explain how constellations of interpersonal relations at the house transformed over the course of one semester and what factors-environmental, social, and individual-were responsible for those changes. In addition to the close description of network graphs based on the survey, we also present three focal cases of international students in which distinct processes of socialization within and beyond the residential hall were observed. By taking a case studies approach, we hope to illuminate the particularities of individual experiences and show the realistic complexity of social network formation. Based on the analysis, we discuss how social experiences of the students in this particular setting can be understood in relation to their language use and development.

\section{Background}

\section{Language Socialization in Study Abroad}

Among various theoretical approaches employed in previous SLA research on SA, one of the most prominent frameworks frequently used in recent studies includes the language socialization (LS) paradigm (Schieffelin \& Ochs, 1986). LS, which derives from the general sociological/anthropological tradition in the endeavor of understanding human development along with language acquisition, has been enthusiastically applied to SLA studies over the past decade or so (Duff, 2007; Duff \& Talmy, 2011; Zappa-Hollman \& Duff, 2015). One fundamental tenet of LS is its attention to the sociality of human development inseparable from language. Development is conceptualized as the process of participation in society, where norms, values, and concepts are practiced and acquired through language. By regarding language as an inevitable part of socialization, LS aims to capture the entirety of complex human development (Kramsch \& Steffensen, 2008). Therefore, the analytical scope of this paradigm encompasses not only individual learners and their 
agency (e.g., Allen, 2010; Jackson, 2008, 2013), but also their surroundings, including various environmental affordances and social entities in which they partake (e.g., Campbell, 2011, 2015; Kinginger, 2008).

While past studies placed different degrees of emphasis on various elements that mediate socialization in SA settings, many appear to highlight the relational aspects. In other words, interpersonal relationship has been regarded as the central element responsible for the quality of learning in SA (e.g., Allen, 2010; Campbell, 2011; Coleman, 2015; Dewey, Balnap, \& Hillstron, 2014; Hasegawa, 2019; Kinginger, 2008; Magnan \& Back, 2007). Building rapport with host families and local friends generates the sense of integration and increases access to the local society (Kinginger, 2008; Umino \& Benson, 2016). It would also contribute to the frequent use of local languages (Kinginer, 2008), although simply living with someone does not necessarily guarantee positive outcomes (Allen \& Herron, 2003; Magnan \& Back, 2007; Segalowitz \& Freed, 2004). However, in reality, meeting local people and becoming better acquainted with them pose numerous challenges for international students (Allen, Dristas, \& Mills, 2006; Campbell, 2011; Dewey, Ring, Gardner, \& Belnap, 2013; Kinginger, 2009; Trentman, 2013). Coleman's (2013) model of social circles inherent in SA settings neatly captures this dilemma. According to Coleman, three layers of social circles are relevant to SA participants; namely, co-nationals, other outsiders, and locals. There is a clear tendency for SA participants' relationships to start from the inner circle (co-nationals) and expand to the outer circles (other outsiders and then locals). In other words, rapport building with locals is prone to occur after bonds have been created with co-nationals and other outsiders (e.g., foreign nationals). While there are certainly various factors to consider in interpreting this model, the kind of challenges likely faced by SA students should be approached and investigated as programmatic issues rather than being considered merely individual differences.

Despite the strong interest in relational aspects of SA, the majority of past research referred-more or less exclusively - to individual relationships rather than collective constellations of relations (e.g., networks). This may be due in part to the fact that the above-mentioned studies focused on the perspectives of the selected focal individuals and overlooked their surrounding actors (e.g., friends and acquaintances) as well as their connections. Kinginger (2009) shares a similar sentiment, stating "Qualitative researchers should broaden their perspectives beyond the students, to include other people who shape the nature of study abroad" (p. 217). It is also true that these studies did not make use of an analytical framework suitable for examining social groups. Individual relationships are always embedded in a larger network where multiple actors are intricately related. Depending on the individuals' positioning in the web of relations, they would be given access to different social support and resources, 
which all give rise to the processes and outcomes of learning (Zappa-Hollman \& Duff, 2015).

In the past few years, an emerging number of SLA scholars have incorporated some concepts of social network (e.g., Dewey, Bown, \& Eggett, 2012; Isabelli-García, 2006; Kurata, 2011). For example, Isabelli-García (2006) examined Anglophone learners of Spanish studying in Argentina and found that the students who established extensive social networks, as compared with those who did not, developed more proficiency. This makes sense intuitively, but a more or less contrastive finding was suggested by Dewey, Ring, Gardner, and Belnap (2013), who examined the formation of social networks by learners of Arabic in Jordan and Egypt. The authors stated that the quality of linguistic interaction may not be determined by the type of social networks that learners formed. These studies relied primarily on quantifiable (e.g., number of connections) or dichotomous data (e.g., strong or weak relations) to infer students' social networks, which may not capture the subtlety and the complexity of relationships. As we propose to show, far more complex reality is involved in social network formation in SA.

\section{Changing Environments of Study Abroad: EMI}

International students' experiences are not only shaped variously across individual learners and specific contexts, but they are also susceptible to historical and political conditions. For example, with the globalization of higher education institutions accelerating everywhere, we have observed a drastic increase in the number of programs that make use of English as a medium of instruction or English Medium Instruction (EMI) in non-English-speaking countries across the world (Macaro, Curle, Pun, An, \& Dearden, 2018), and notably, in Asia (Kedzierski, 2016; Kirkpatrick, 2011; Leong, 2017; Taguchi, 2014). In consequence, the experiences of international students in those countries have presumably changed from when only local languages were used as a main instructional medium (Isabelli-García et al., 2018). While EMI itself is not a new concept, the current increase of EMI has been unprecedentedly rapid due to the growing pressure for the globalization of university campuses, as well as the financial and reputational consequences attached to it (Walkinshaw, FentonSmith, \& Humphreys, 2017).

The present research context-Japan-is also undergoing the pressure of globalization as a society that has been long perceived as homogenous and monolingual. We see this pressure, for example, in a multimillion-dollar governmental grant program, entitled 'Top Global University (TGU) Project.' The underlying rationale for this program is to support the globalization of Japanese universities and to increase their prominence in the world university ranking. The TGU project started in 2014 with 37 universities - with each of which having 
presented different programmatic proposals—selected to receive the ten-year grant.

The EMI movement is slowly yet steadily changing the ways in which students go through socialization processes. There have been emerging discussions on the new roles of English and the accompanying consequences from the perspectives of English as a lingua franca and global Englishes (e.g., Leong, 2017; Taguchi, 2014), for example. However, as yet, there are no firm data regarding the impact of EMI on students' LS process across the campus, including international students' acquisition of local languages and cultures. International students on EMI campuses may not be required to be familiar with or functional in local languages and cultures, which may potentially hinder their integration into local communities and diminish their opportunities for cross-cultural learning. Needless to say, such lost opportunities are especially crucial for those who are hoping to learn local languages and cultures while they are abroad. We know little about such students' experiences, including their LS process on EMI campuses.

\section{The Present Study}

\section{Research Objectives}

As an initial step toward a better understanding of the complex and changing nature of international SA students' LS process, in this study, we will look closely into the ways in which interpersonal relationships were formed and transformed on an EMI university campus in Japan. In particular, we focus on a social network formed at a residential hall called the Nihongo House (Japanese language house). The Nihongo House is a part of a residential unit created by the university with the objective of providing a viable living-learning environment for its students and promoting interactions between domestic and international students according to common interests and skills. In fact, the focal university, "Japanese University ${ }^{1}$," is known as a forerunner of EMI in Japan and is one of the recipients of the TGU Project grant. Their "24-hour liberal arts education” program began in Spring 2015 with three themed houses, including "Japanese Culture and Arts House," "Graduate Track House," and "Public Policy House." Nihongo House and four other houses ${ }^{2}$ were added in Spring 2016 to replace the Graduate Track House and the Public Policy House, which were discontinued because of a shortage of applicants. Similar to typical foreign language residences found in North America (e.g., Matsunaga, 2012), the

\footnotetext{
${ }^{1}$ A pseudonym is used here.

2 They are "Entrepreneur House," "Fitness House," "International Custom House," and "Romance Language House."
} 
Nihongo House is located on a campus where English is used as a medium of instruction. The necessity of upholding the use of Japanese as the common objective emerges from this setting. However, what adds intricacy to the present situation is the fact that the university is located in Japan, where Japanese is spoken outside the campus and even on the campus among domestic students outside of classes.

In order to examine the process of interpersonal relationships developed at the Nihongo House, we employed social network analysis (SNA) as our primary analytical framework (e.g., Borgatti, Everett, \& Johnson, 2013). SNA was born in sociology and later developed into a multidimensional and versatile analytical framework, owing partly to the development of graph theory (Carrigan \& Scott, 2011). Its strength lies in its strictly data-driven approach to understanding of structural properties of relations among actors. With a particular emphasis on the complexity and subtlety involved in the formation and transformation of social networks, this study seeks to answer the following research questions:

a) How are interpersonal relationships formed at the Nihongo House?

b) What hinders or promotes the building of relationships for international students living in the Nihongo House?

Evidently, the central object of analysis is interpersonal relationship, rather than particular instances of Japanese language use, which typically receives a primary focus in LS research. Nonetheless, interpersonal relationship is tightly linked with each student's engagement in various social activities, which, of course, include conversations (Hasegawa, 2019). Hence, we discuss language use and its potentials for language development in terms of affordances (or constraints) generated through interpersonal relationships.

\section{Research Context and Participants}

As discussed above, Japanese University is known as one of the leading universities for international education in Japan. As of April 2018, Japanese University had enrolled 884 degree-seeking students, of which 22 were international students. The university was also accepting over 150 international students through their exchange partnerships with overseas institutions in 29 countries. Therefore, while international students made up about $15 \%$ of the campus population, most of them stayed there only for a semester or a year.

The Themed House project is one of four major pillars that Japanese University presented in their TGU grant application with its ambition to become a world class liberal arts college in 10 years. It aims to deliver "around-the-clock liberal arts education" through an introduction of themed houses, which were expected to serve as "learning dormitories." According to the application 
document circulated for a recruitment purpose, the main objectives of the Nihongo House were twofold:

(1) To provide short-term exchange students with a Japanese language immersion environment where they can communicate in Japanese with other members of the House on a daily basis.

(2) To provide Japanese students with opportunities to interact intimately with exchange students through communication in Japanese.

The document discusses additional positive effects expected from living in the house: The Japanese language immersion environment offers a good practice field for improving Japanese language skills for international students. This environment also helps both Japanese and international students deepen their understanding of not only Japanese culture but also other cultures and values, which nurtures flexible and open-minded attitudes.

The Nihongo House began in Spring 2016, with 12 Japanese students and 6 international students. In the following semester (Fall 2016)—when we collected data for this study -5 students remained in the house while 9 students newly joined. A list of the students with pseudonyms and their brief backgrounds is provided in Table 1 . All the residents gave us consent to participate in this study.

\section{TABLE 1. LIST OF RESIDENTS}

\begin{tabular}{|c|c|c|c|c|c|}
\hline Name & $\begin{array}{c}\text { Home } \\
\text { Region/Country }\end{array}$ & $\begin{array}{c}\text { First } \\
\text { Language }\end{array}$ & Sex & Roommate & $\begin{array}{c}\text { Lived in Nihongo House } \\
\text { in Prior Semester }\end{array}$ \\
\hline Ann & Europe & Other & $\mathrm{F}$ & Rie & No \\
\hline Mary & Europe & Other & $\mathrm{F}$ & Aki & No \\
\hline Pam & Asia & Other & $\mathrm{F}$ & Mika & No \\
\hline Ross & North America & Other & M & Ken & No \\
\hline Zadie & North America & English & $\mathrm{F}$ & Saya & No \\
\hline Ruby & North America & English & $\mathrm{F}$ & Yoko & No \\
\hline Sue & Asia & Other & $\mathrm{F}$ & Mika & No \\
\hline Mika & Japan & Japanese & $\mathrm{F}$ & Pam & Yes \\
\hline Rie & Japan & Japanese & $\mathrm{F}$ & Ann & Yes \\
\hline Saya & Japan & Japanese & $\mathrm{F}$ & Zadie & Yes \\
\hline Aki & Japan & Japanese & $\mathrm{F}$ & Mary & No \\
\hline Ken & Japan & Japanese & $\mathrm{M}$ & Ross & No \\
\hline Yoko & Japan & Japanese & $\mathrm{F}$ & Ruby & Yes \\
\hline Keiko & Japan & Japanese & $\mathrm{F}$ & Sue & Yes \\
\hline
\end{tabular}

International students and Japanese students were coupled to live as roommates. This arrangement was intended to provide daily, spontaneous opportunities where students interact with one another, help each other, and learn from each other, which would help achieve the said goals. The matching 
was done by the Student Affairs office based on the results of questionnaire survey that asked each student about their personality, study and social habit, and other life-style preferences.

The house was not located in a typical dorm-style residence hall where rooms are linked to the hallway inside the building, as well as to a lounge space and a shared entrance to the building. Rather, it was in an apartment-style building, and each unit was facing outside with a separate entrance (Figure 1). This physical layout made it difficult for the residents to mingle easily beyond their respective units. Therefore, one apartment was designated as a communal space or the "lounge" for the residents.

\section{FIGURE 1. PHOTO OF NIHONGO HOUSE}

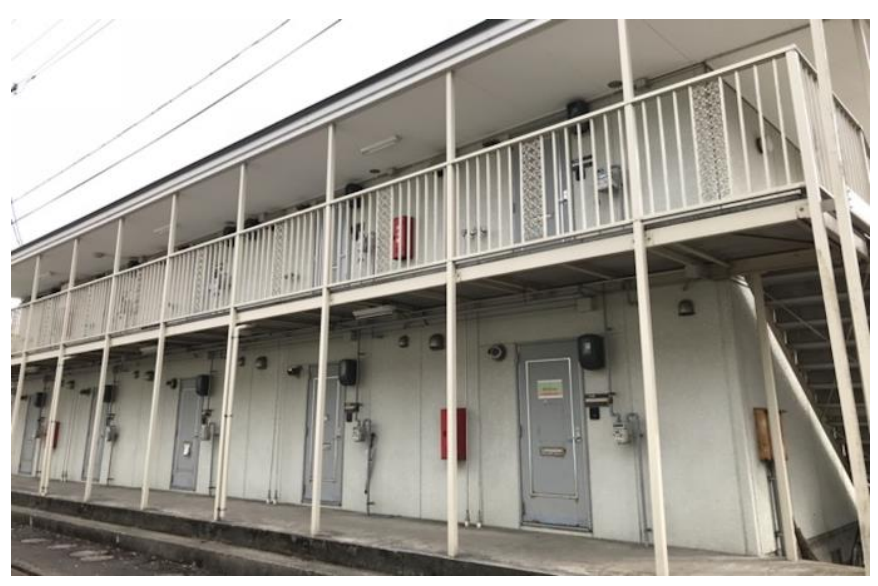

There were two official activities, in which all residents were expected to take part at the house in order to accomplish the aforementioned goals. First, the residents were expected to participate in weekly meetings (12 meetings in total throughout the course of a semester), at which house activities were discussed and planned. Second, there were excursions to nearby locations, as well as seasonal events and parties, which were planned by the residents at the weekly meetings. Beyond these official activities, the residents were encouraged to engage in spontaneous exchanges with one another although no measure to promote such interaction beyond the provision of the lounge space, equipped with furniture, electric appliances, and study materials such as books, DVDs, and board games, was taken.

\section{Research Procedure}

In order to collect relational information for SNA from the Nihongo House residents, we created a survey instrument (see Appendix) based on the 
previous instruments developed for SNA (e.g., De Lange, Agneessens, \& Waege, 2004; Romney \& Weller, 1984). Along with the demographic questions, the survey asked each resident the following SNA questions:

(a) Do you consider this person as a friend or someone you would like to hang out with in your spare time? (Friend index)

(b) How close do you feel to this person? (Closeness index)

(c) How often did you interact with this person beyond the classroom since you arrived in Japan? (Interaction index)

These questions-called name interpreter-were aimed to elicit different kinds of relational ties between the residents. For each item, the house residents were asked to rate their relationships with the individuals on the roster. For example, for the closeness index, each resident rated his/her closeness levels with others, using a sliding scale of 0 (“distant") to 3 ("very close"). In addition, they were also asked to write in additional names of individuals with whom they hang out beyond the Nihongo House and to assess their relationships in the same way. This way, a fuller picture of the network of residents within and beyond the house could be obtained.

The survey was conducted twice-at the beginning and the end of the semester-which allowed us to examine any changes in relational ties and configurations over time. We obtained consent from all the residents to participate in this study, and all of them submitted their responses to the first survey. However, as the semester proceeded, it became increasingly difficult to get a hold of some students-Yoko and Keiko in particular-from whom we could not collect responses in the end of the semester. While we acknowledge that the missing responses could affect the overall representation of the network, we ensured to proceed our analysis with much care. Moreover, the fact that these students were difficult to reach to is suggestive of their invisibility in the network, which we will take up later in the discussion section.

The collected responses were plotted into an Excel file for analysis and visualization with the SNA software, Gephi (Bastian, Heymann, \& Jacomy, 2009). SNA excels at summarizing large data in a visually effective way by graphing the structural properties of relationships among actors. However, the very strength of SNA may also undermine the subtlety of individual cases in question. Therefore, in order to achieve a holistic and nuanced understanding of the socialization process, we also collected ethnographic information through participant observation, semi-structured interviews, documents, and questionnaires. These pieces of information also helped us commit to careful analysis of the data and compensate for the missing responses. The analysis section that follows this will be organized first with the presentation of network 
graphs and then with the discussion of focal cases of individuals that showed particularly distinctive processes of socialization.

\section{Network Formation at the Nihongo House}

\section{Semester Beginning}

This section presents SNA graphs and our analysis of them. Based on the responses obtained through the survey conducted in the beginning of the semester, we created a graph representation of how people in the Nihongo House were connected with one another. Figure 2 shows the closeness network ${ }^{3}$ with only the house residents represented. The circles (i.e., nodes) in the graph represent individuals (i.e., actors). The pseudonyms of the house residents are presented in the nodes. The red nodes represent Japanese residents, while the blue nodes are international residents. The arrows that connect the nodes are relational ties, with the strength of closeness (i.e., 1-less than close, 2-close, 3very close) expressed by the thickness of arrows. That is, the thicker the arrow, the closer that the respondent felt toward the other.

\section{FIGURE 2. CLOSENESS NETWORK AT THE SEMESTER BEGINNING (RESIDENTS ONLY)}

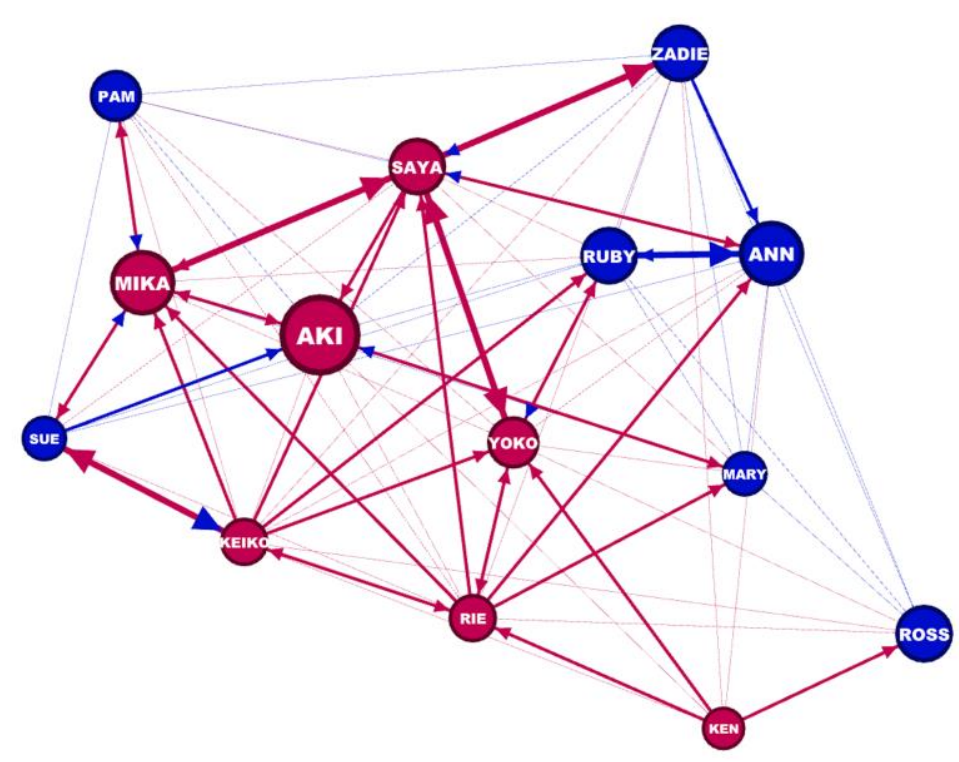

A cursory examination of this graph gives an impression that many residents are connected with each other with a number of arrows between each

\footnotetext{
${ }^{3}$ We only use the closeness index in this article because it turned out to be the most robust index in terms of illuminating interpersonal relationships and subgroups with this group.
} 
node. The overall density of this graph, calculated as the sum of all ties divided by the sum of all possible ties, is 0.549 , which means that $54.9 \%$ of all possible ties is realized in this graph. Although this number may seem high, as we look closer at the strength of ties, it becomes apparent that most of them are weak ties (i.e., "less than close" $=1$ ). In fact, most of the thicker ties are originated from the Japanese residents ${ }^{4}$. Furthermore, the size of the nodes is also adjusted to represent the number and the strength of incoming ties that each actor received from others. This means, then, the larger the node is, the more ties and/or the stronger ties that individual received from others. Therefore, apparently, Aki is the most 'popular' actor in this network while Ken appears to be noticeably 'unpopular' among the residents.

The layout of the graph also requires some explanation. This graph layout, Force Atlas (Jacomy, Venturini, Heymann, \& Bastian, 2014), aims to arrange nodes so as to shorten the distances of arrows and minimize the number of crossings of arrows as much as possible. It is effective in showing how individual actors can be grouped together in terms of relative connectedness and non-connectedness with others. That is to say, the closer the actors are placed, the more socially related they are, and the farther apart they are placed, the less they are linked. At first glance, it is clear that Japanese students are positioned in the center and relatively close to each other, with stronger ties among them. An exception to this is Ken, who is placed rather remotely from the crowd. In contrast to the Japanese residents, international students are peripherally placed without having strong ties to one another, except for a few ties-including Ruby and Ann-who seemingly have closer connections. This layout points to some interesting information about the relationships existing in this house. For example, the relationships among the Japanese residents appear to be group-based because they share mutual connections among them. This contrasts with the international students, who appear to have more individual-based connections. As a matter of fact, Saya, Yoko, Keiko, and Rie had known each other prior to the beginning of the semester. These pre-existing connections that point to a shared history are observable in the beginning state of this network.

Although many observations can be made from the above graph, this visualization is still incomplete because it does not show relationships beyond the Nihongo House. A more complete picture is shown in Figure 3. Non-residents are represented by gray nodes.

\footnotetext{
${ }^{4}$ The coloring of the arrows depends on the color of the originating nodes (i.e., red nodes and red arrows).
} 


\section{FIGURE 3. CLOSENESS NETWORK AT THE SEMESTER BEGINNING} (RESIDENTS + THEIR CONNECTIONS)

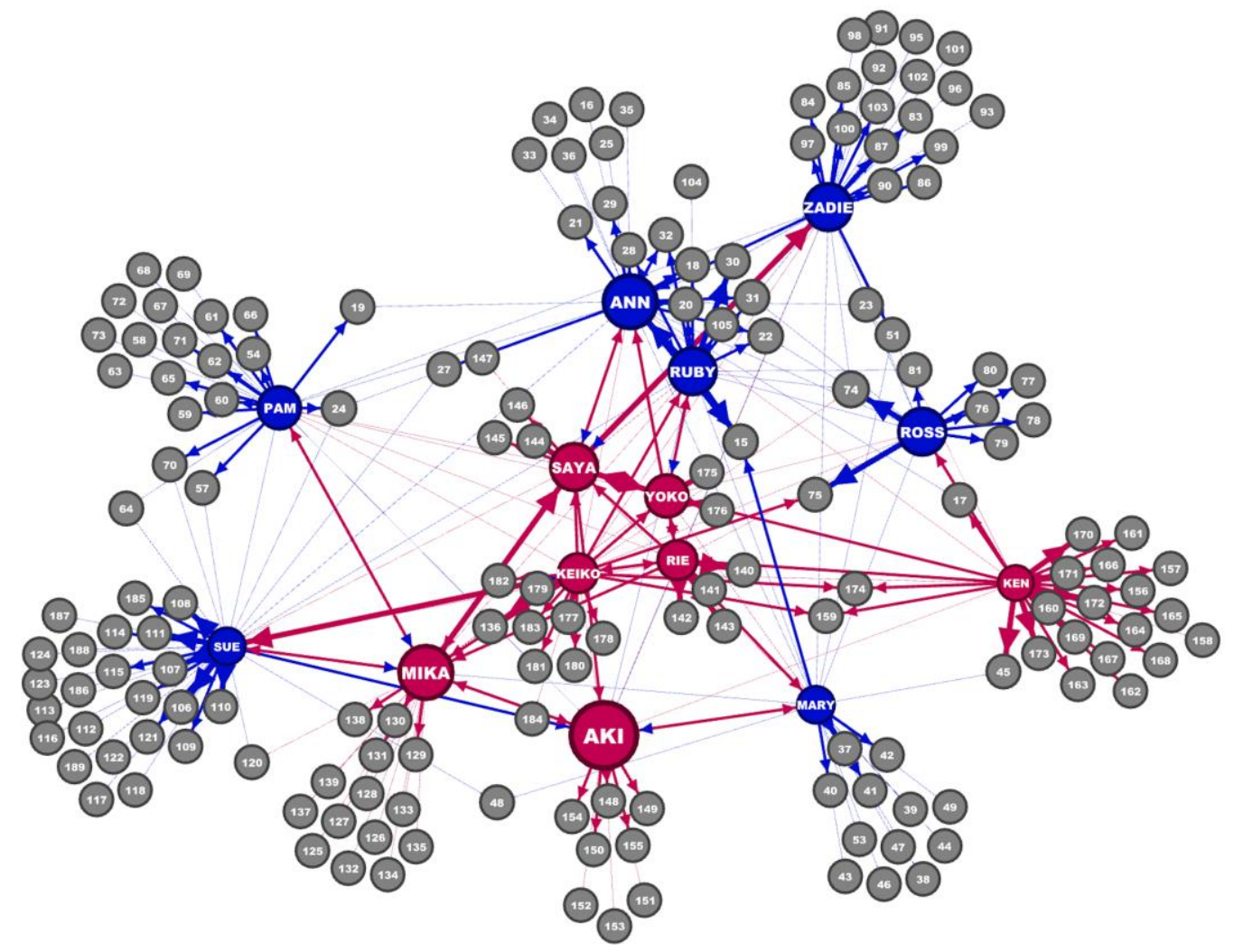

With connections beyond the house added, the graph permits a more comprehensive analysis. First, Ken, who received the least degree of ties, in fact has connections outside the house. To be precise, more of his connections are found with people outside the house than with the house residents. Second, Ann and Ruby share some ties with non-residents, which seemingly places them closer in the graph. Third, the four Japanese residents who have prior relationships (i.e., Saya, Yoko, Keiko, and Rie) are positioned closer to one another in this graph, clearly reflecting their preexisting ties. Interestingly, they do not have many distinct connections outside the house, which places them in the center position of the graph. In contrast, individuals with unique ties outside the house are placed more or less peripherally because their connections are not shared by others in the house.

It is worth noting that roommate relationships are not necessarily the determinant of the relative positioning of residents in this graph. Some 
roommate pairs, such as Aki-Mary, Ken-Ross, and Yoko-Ruby, are positioned close to each other, which points to not only their relationship with each other but also their positioning in the entire network. However, most other roommates are not necessarily located in the vicinity of each other. This aspect will be discussed further in the latter half of this article. Finally, among the international residents, an interesting divide between Asian students and nonAsian students may be discernible from this graph. The students located in the left side of the graph, including Pam and Sue, are ethnically Asian, whereas Zadie, Ann, Ruby, Ross, and Mary are ethnically non-Asian. This observation points to the propensity of relations being formed around ethnic/racial backgrounds, to some extent at least, which can coincide with various issues, such as having common friends, shared linguistic and cultural backgrounds, and similar Japanese proficiencies that determine course placement, among others. All these factors are potentially interesting research topics in their own right. However, given the limited information currently available, we will confine our remarks on this issue to Sue's case only, which we will closely examine later.

In sum, the Nihongo House does not appear to have one (or several) coherent structure at the beginning of the semester. Rather, individuals' prior relationships within and beyond the house appear to be the dominant pattern of connections. The Japanese residents are more closely connected with the other housemates, whereas international students tend to be more related with people outside the house. This portrayal may suggest that the Japanese residents are occupying the pivotal position. However, in fact, it does not coincide with the observation of the second author who served as a faculty mentor of the Nihongo House. As far as the observation is concerned, some of the Japanese residents, such as Mika and Aki, certainly played a central role in the house by assuming leadership, but the other Japanese students (Yoko, Rie, and Keiko), appeared less visible to the observer because they did not actively participate in official activities and events in which the second author took part. This discrepancy is a vital point to consider because it reminds us that residents' experiences may not completely be captured solely in the public sphere during official activities and events. Socialization happening in the private sphere-to which researchers do not have access-may play a large part in the overall social experience of the residents. It also raises a question concerning the role of official activities and events in network formation, as compared with more personal and spontaneous interactions and exchanges that the residents experience on a daily basis. What we see here are multiple layers of relationships that each resident is a part of, which will become more complex towards the end of the semester. 


\section{Semester End}

The initial relationships formed by the residents changed over the course of the semester. Figure 4 below shows the closeness network of the residents at the end of the semester.

\section{FIGURE 4. CLOSENESS NETWORK AT THE SEMESTER END (RESIDENTS ONLY)}

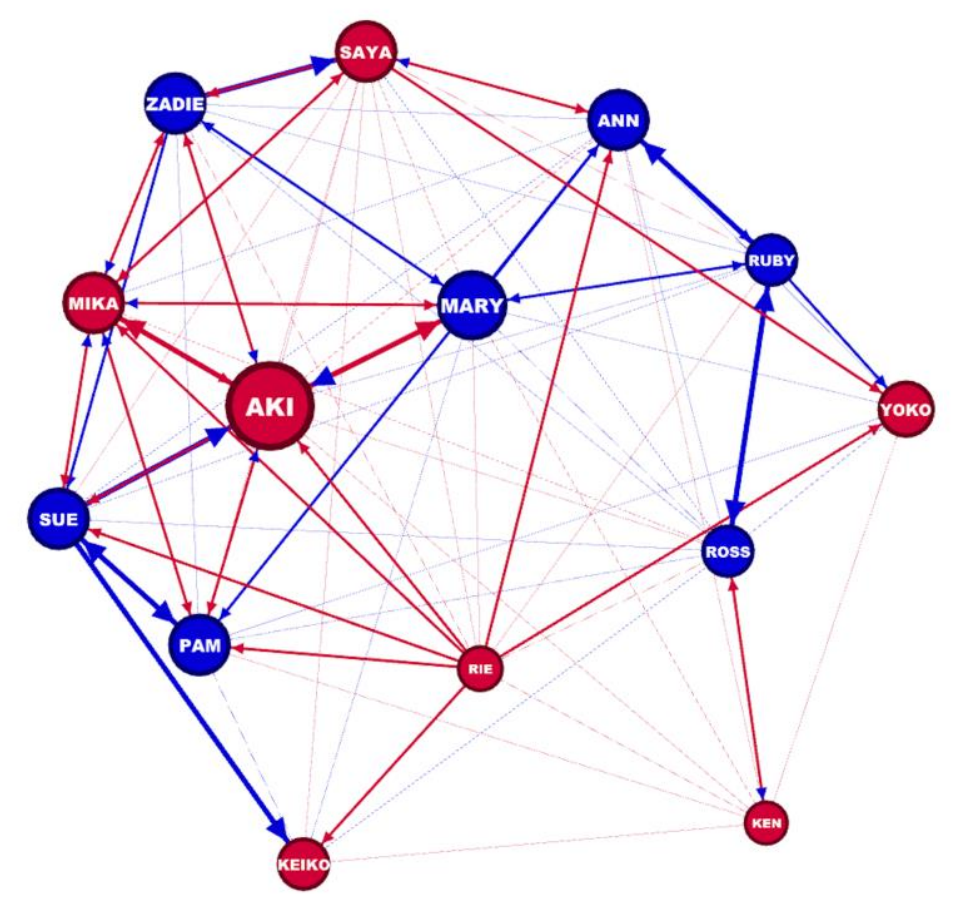

At first glance, it is apparent that the gap between international and domestic students found in the beginning has lessened in this graph. To be more accurate, with a noticeable overall increase of stronger ties (i.e., thicker lines), both groups are better connected with one another. This indicates that inter-resident relations have become more solidified and denser than in the beginning ${ }^{5}$. The network density of 0.642 -which means $64.2 \%$ of possible ties is realized in this graph-also shows an increase from the semester beginning. As evident from the node size, Aki received the highest in-degree scores (i.e., other people considered her to be close with them), and so she is clearly occupying the central position in this network. Interestingly, her roommate, Mary, has also increased her 'popularity' with stronger in-degree scores, which is again represented by

\footnotetext{
${ }^{5}$ Note that Yoko and Keiko did not respond to the second survey. Thus, the connections with them are not fully presented in the graph.
} 
the node size. This change is obvious when compared with Mary's initial status in Figure 2. Mary has gained more central positioning in this network. We will take up her case later and discuss how such a change occurred in the next section.

Now, let us examine the graph with non-residents (i.e., gray nodes) added to the network (Figure 5).

FIGURE 5. CLOSENESS NETWORK AT THE SEMESTER END (RESIDENTS + THEIR CONNECTIONS)

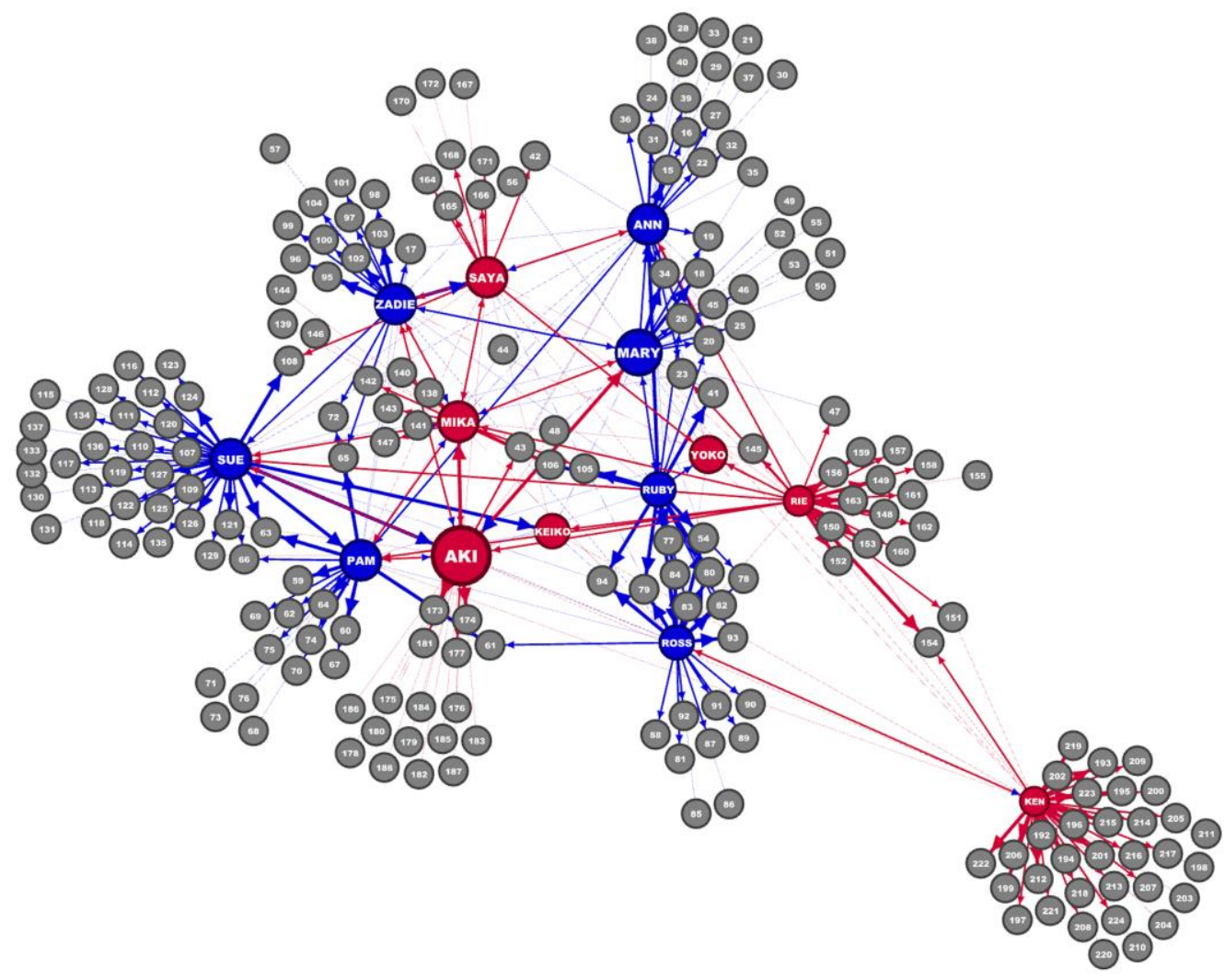

Of special note is Ken, who is positioned remotely from the rest of the house. Ken was already at the periphery of the network in the beginning, but the extent to which he is peripheral to the network apparently intensified as he made more connections outside the house. Indeed, according to the observation notes and the interview that the second author conducted with him, Ken became increasingly busy with the activities of the student organization in which he served as the president. With his increased commitment in activities outside of the Nihongo House, Ken's relationships with the other residents faded as the semester proceeded, and in the end, his roommate-Ross-remained his only connection to the group. 
Moreover, what seems observable from the graph is the relatively high density area among the residents in the left side of this graph, including Aki, Mika, Sue, Pam, Zadie, and to a lesser extent, Saya and Keiko, on the one hand, and the residents on the right side, including Ann, Mary, Ruby, and Ross, who have some common friends outside the house, on the other hand. As a matter of fact, the group of residents on the left side of the graph was often observed together in the common lounge where people would eat, chat, study, and so forth. This lounge had a traditional Japanese table called kotatsu (blanketcovered, heated table for keeping legs warm in the cold winter), which was indeed one of the reasons that drew people together (Figure 6).

FIGURE 6. KOTATSU LOUNGE

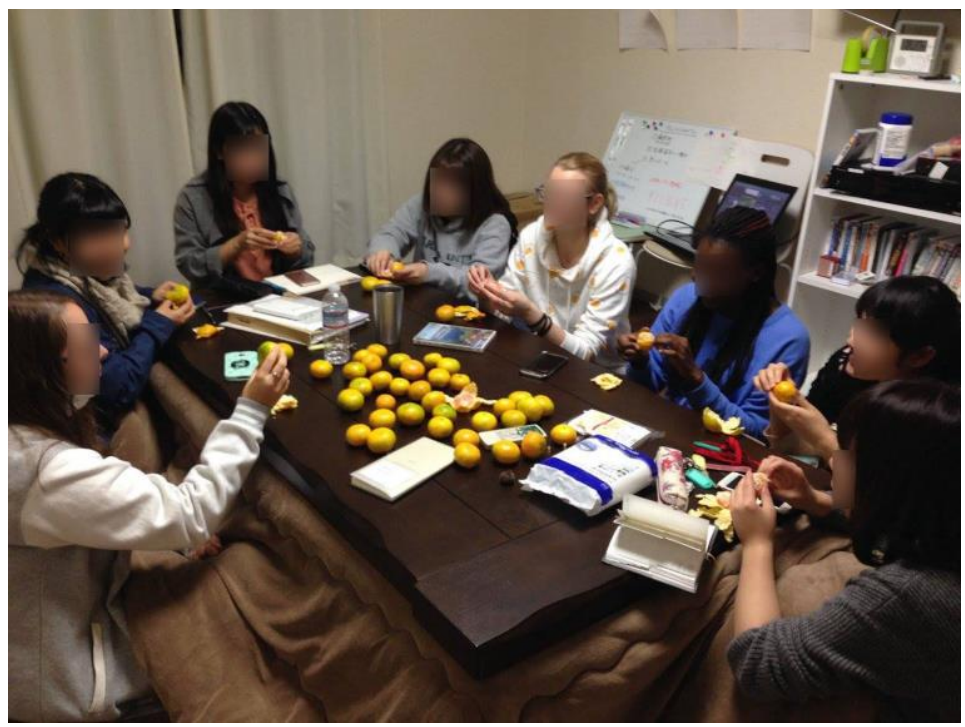

Japanese University is located in the region that gets very cold in the wintertime. In order to save electricity in each unit, which is billed to individuals according to their use, some students would choose to spend time in the lounge and sit around the warm kotatsu rather than staying in their own rooms. In this way, the lounge became a space of spontaneous socialization for some residents. Conversely, the students in the right side of the graph were those who rarely participated in the kotatsu socialization.

To summarize the changes observed in the Nihongo House network, the overall gap between the domestic and international students disappeared, and the residents formed firmer connections within the house boundary. Some students, notably Ken, however, faded away from the house network due to their house-external connections. Noticeable group connections were formed apparently through daily gathering in the common lounge area. In this group, 
two Japanese residents, Mika and Aki, were observed to take a leadership role in keeping the conversations in Japanese and maintaining some order ${ }^{6}$. While this kotatsu lounge created a spontaneous place where people could gather and speak Japanese, which is namely the very purpose of the Nihongo House, it also contributed to dividing the house residents into those who were in the group and those who were out. Depending on the groups the residents belonged to, not only their language use behavior varied, but their perceived sentiments towards this institutional setup also differed. We will now take up three particular cases of international students who underwent distinctive experiences.

\section{Three Cases of Socialization in the Nihongo}

\section{House}

The whole network examined thus far can provide information as to how the Nihongo House as a constellation of interpersonal relations came into being and how its configurations have changed as the semester proceeded. The above analysis also points to individuals' unique positioning in the network and their connections within and beyond the house. These pieces of information permit certain conjectures concerning various socialization processes of the residents. In this section, our attention turns to three individuals-Ann, Mary, and Sue-and we closely examine how their socialization processes unfolded during the semester. These three students were chosen because of their unique forms of participation in the Nihongo House. Although the goal of this section is not to present generalizable findings to other individuals in different contexts, there are multitude of practical implications that can be drawn from these cases, which we will address in the final section.

\section{Ann's Case}

Ann is an exchange student from Eastern Europe. She lived in the Nihongo House in her first semester and moved to a regular residence hall in the following semester. She signed up to live in the Nihongo House with a strong desire to improve her Japanese speaking ability. In her application document, she wrote:

I believe that the best way to learn and become truly fluent in any language is to use it daily for communication... As somebody who has studied the Japanese language for almost 5 years and has broad vocabulary, as well as deep understanding of Japanese grammar, I still find my level of communication ability unsatisfying. While this opportunity to study in Japan for a full year will have an undeniable and

\footnotetext{
${ }^{6}$ Although the actual conversation data were not collected, the second author observed numerous incidents where Mika and Aki took lead in the conversations in the lounge space.
} 
extremely positive influence on my speaking in Japanese abilities, I still wish to challenge myself to become as fluent in Japanese as it is possible during the stay.

Ann had studied Japanese for five years prior to coming to Japan, but she apparently considered her speaking ability to be inadequate. This motivated her to want to live in the Nihongo House, as she repeatedly expressed in her interview and in the questionnaires done at the beginning and end of the semester. Ann participated in almost all official house activities, including the weekly meetings and the fieldtrips. Her active participation in these activities also reflects her strong desire to improve her Japanese speaking ability. However, Ann decided to leave the house after one semester, because she apparently did not get enough practice by living in the Nihongo House. One may wonder how this could happen despite her strong motivation.

\section{FIGURE 7. ANN'S EGOCENTRIC NETWORK AT THE SEMESTER BEGINNING}

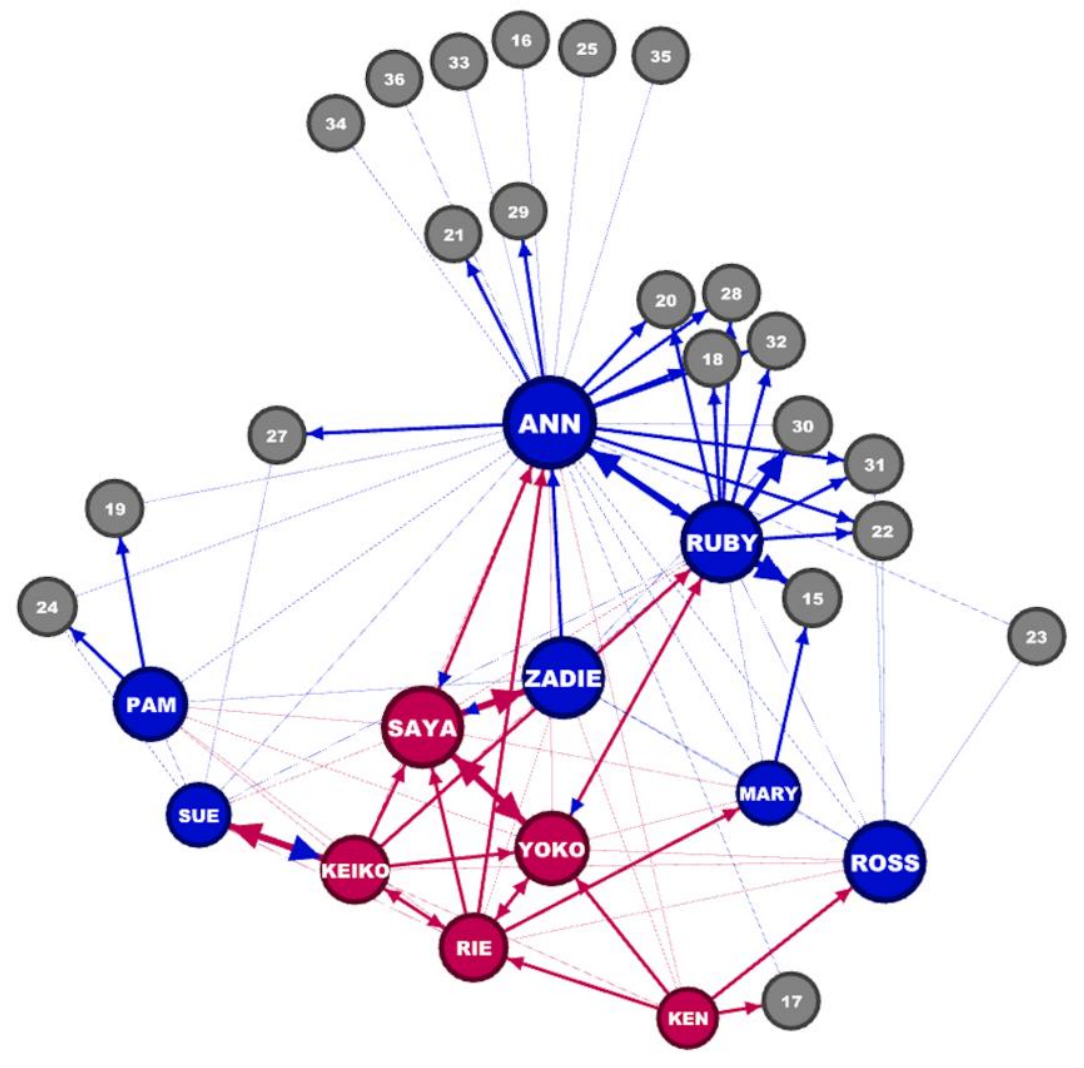

Figure 7 presents Ann's egocentric network in the beginning of the semester. This graph is based on the same closeness index, but this one only 
shows people with whom Ann is connected. In other words, it presents Ann's closeness network from her viewpoint only. Ann is relatively well connected with the other residents with 14 incoming ties, which makes her one of the most 'popular' of the international residents. This is represented by the size of the node as well. Ruby is positioned closely to Ann, which is explained by the fact that they were taking the same class and sharing mutual friends beyond the house.

She is connected with five Japanese students, Saya, Yoko, Keiko, Rie, and Ken. Note that Ann's roommate, Rie, is positioned relatively remotely from her. In fact, Ann reported having a problematic relationship with Rie in the interview. Prompted to discuss her relationship with Rie, Ann stated:

ルームメイトとあまり話しませんでしたから(as I did not speak much with my roommate), practice あまりできませんでした (I couldn’t practice much). There were times when she came back at 6 in the morning or so, and call her friends and talk loudly and wake me up and I think she started her time, not using lounge room because I was European, I'm European and European sleep for, a lot. So, it’s, ah, I mean, I don't think she did it because she wanted to be mean. (Interviewer: different lifestyles?) Yeah, yeah, but it wasn’t matched, so... Ah, I did talk to her, but it's a, I mean, didn't really help. Generally, she is really nice and I think it's the first time she lived with a foreigner. So, I think that's why she still had some expectations. [Ann, Interview ${ }^{7}$ on $2 / 2 / 2017$ ]

It is easily imagined that roommates are the first and foremost relationship that each resident develops in the Nihongo House. It is the primary relationship by design in the sense that they would expectedly spend a lot of time together, which would also entail a lot of Japanese speaking opportunities. In Ann's case, however, this situation did not meet her expectations. She instead became friends with Saya for the commonalities they shared, such as being vegetarians and having the same hobbies of knitting and cooking.

Actually, I spent a lot of time with Saya-san. (Interviewer: Do you think Saya-san is your friend?) Yes. We're both vegetarian. We became friends because of that, actually. And I like knitting, and Saya wanted to learn how to knit. So we started knitting together and just then we cook together couples of times. [Ann, Interview on 2/2/2017]

In the final questionnaire, Ann picked Saya to be the closest person in the Nihongo House. Her emerging friendship, however, did not necessarily lead to more speaking practice for Ann. Now that she moved out to a different hall

\footnotetext{
${ }^{7}$ Interviews were conducted in English unless otherwise noted.
} 
and is living with a Taiwanese student, she seems to be getting more opportunities to speak Japanese.

She's a Taiwanese, and, but Taiwanese people usually good at Japanese. And I think she's 500 level $^{8}$. (Interviewer: Do you use Japanese when you talk to her?) Yes. She usually use in Japanese. So, it actually get more Japanese practices. [Ann, Interview on 2/2/2017]

During the interview conducted with Ann, she recounted her experience at the Nihongo House. If she were to do it all over again, she said she would spend more time in the common lounge area, where people sat around kotatsu and chatted in Japanese. Ann did acknowledge the utility of the lounge space for speaking practice, but she hesitated to go in there because people hanging there were not her friends. It should be noted that in Ann's egocentric network discussed above, Aki and Mika-two of the students who took the leadership role in the house-are missing. That is, she did not have access to the two 'popular' Japanese residents who were leading the kotatsu gathering. While the cause for this is unclear, the consequence resulted in lost opportunities to speak Japanese and her overall dissatisfaction of the Nihongo House.

Ann's case exposes interesting layers of socialization present in the Nihongo House. That is, while she made connections through official activities, she was not part of the lounge-kotatsu group, where Japanese was spoken most of the time. Due to not being on good terms with her roommate and not being a member of the lounge-kotatsu group, Ann apparently missed out the opportunities to use Japanese on a daily basis. All this happened despite her clear intention to practice speaking Japanese while living in the Nihongo House. Ann's case is also indicative of different geneses of relationships, namely, those that develop through organized activities vs. spontaneous activities. She developed a friendship with Saya, who was not her roommate, but who shared some commonalities. Ann also recalled her relationship with Aki, who organized many events for the residents.

And I think it's same for Aki-san. She's really, really nice and understanding. But, she's still, um, someone you interact for the purpose of organizing and participating for the Japanese house activities, yeah, but not someone you interact with in your free time and private time. [Ann, Interview on 2/2/2017]

For Ann, the good relationships that she enjoyed were owing to accidental and spontaneous encounters, rather than through organized activities that she participated in. For students such as Mary, to whom we will turn now, however,

\footnotetext{
${ }^{8}$ The highest-level Japanese course offered at the institution.
} 
the organized encounters were more impactful on the building of their interpersonal relationships.

\section{Mary's Case}

Mary is an exchange student from Western Europe. Unlike Ann, Mary's motivation for living in the Nihongo House was rather vague or passive. Mary stated in the interview that she wanted to improve her Japanese and make friends at the Nihongo House, but she also explained that Nihongo House was her second choice after her application to live in another dorm that had single occupancy rooms was turned down. She also added that she chose Nihongo House over other residence halls because of the practical benefits, such as affordable rent and spacious rooms. Overall, therefore, in contrast to Ann, who did express her strong desire to improve her Japanese speaking ability as a reason for signing up to live in the Nihongo House, Mary's reasoning was multifaceted.

Figure 8 below shows Mary's egocentric network in Week 1. A glance at the figure shows clearly that Mary's personal network is smaller than Ann's. In fact, Mary was one of the least prominent students in the house (after Ken) in terms of the number of incoming ties she received. Mary did not have many outgoing ties either.

FIGURE 8. MARY'S EGOCENTRIC NETWORK AT THE SEMESTER BEGINNING

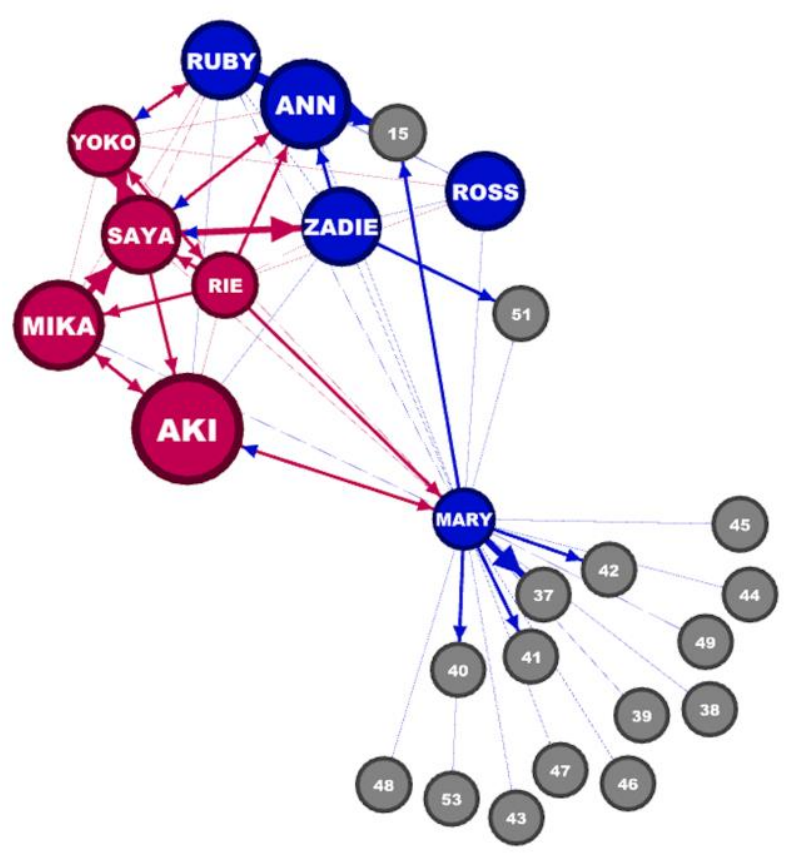


In her questionnaire, Mary realizes and acknowledges that she is the kind of person who feels uneasy about building relationships with people in general.

I have little bit of difficulty to address people I do not know and this project makes it easier to get to know (Japanese) people. [Mary, Questionnaire on 9/7/2016]

I am not very good at building good relationships and making new friends, and so forth. [Mary, Interview on 12/16/2016, original in Japanese $\left.{ }^{9}\right]$

Despite her perceived lack of ability to make friends or build close interpersonal relationships, she reported in the interview that she became close with her roommate, Aki.

Because I saw her (Aki) every day, I became the closest with her. (Interviewer: Is she your friend?) She is a roommate. Because she is my roommate, because I saw her every day in my room, I did not need to go out with her to eat dinner, etc. [Mary, Interview on 12/16/2016, original in Japanese]

Mary picked Aki to be the closest person in the house, but she labeled their relationship as roommates rather than friends. While her definition of 'roommates' and 'friends' is not clear, she acknowledges that she was able to discuss various issues with Aki in Japanese.

(We discussed) various things. When I was studying, if I had questions about Japanese, I asked, and she would say "that's a good question, I'd never thought of it" or "I see, it's similar in [my country] too" and so on. We sometimes discussed economies and refugees and issues like that, but we also talked about food and snacks, and various things. [Mary, Interview on 12/16/2016, original in Japanese]

Regardless of the labels, Mary is happy overall with how her experience at the Nihongo House turned out.

My expectations with my roommate have been met, however, I was sad that due to their busy schedule some of the other Japanese students participated not very often. [Mary, Interview on 12/16/2016]

Mary understands that she was lucky, as compared with the other international students, because her roommate, Aki, was very active in the house, assuming

\footnotetext{
${ }^{9}$ The authors translated all the interview transcripts that were originally produced in Japanese.
} 
leadership and organizing events. Consequently, Mary was able to spend time with Aki not only in her room, but also in the house activities such as cooking, which may have helped her gain more prominence in the network toward the end. In order to see changes in her social circle over time, we present Figure 9 below, which shows her egocentric network in the semester end. The graph clearly shows her increased network size with more connections with the housemates. In terms of the number, Mary came to receive the largest number of incoming ties among the international students in the end.

\section{FIGURE 9. MARY'S EGOCENTRIC NETWORK AT THE SEMESTER END}

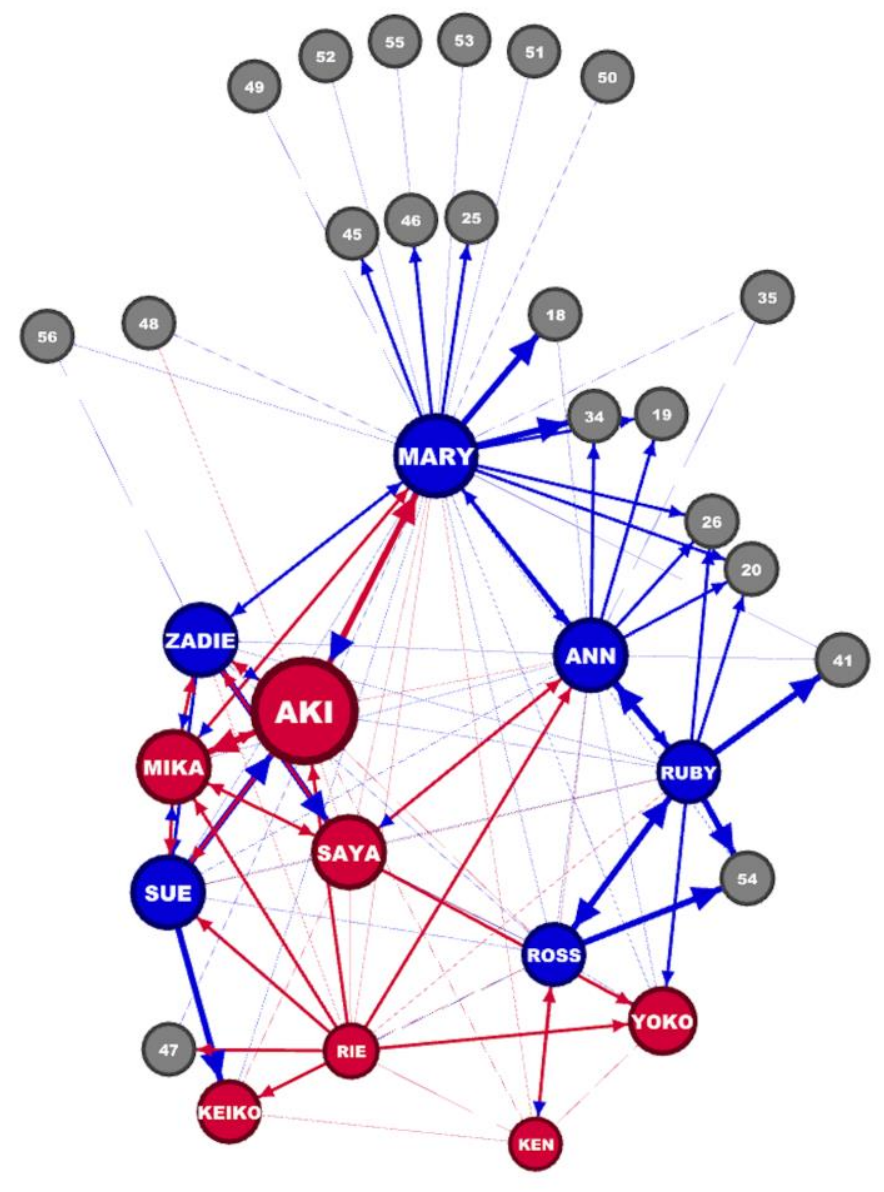

Mary repeatedly stated that she was not good with people and she preferred one-on-one relationships over group-based relationships. Having Aki as her roommate gave her access to both one-on-one and group-based relationships because of Aki's gained status in the house. Aki attested that they 
had at least ten minutes-but usually longer-of conversation each day. However, her assessment of relationships with the other housemates (besides Aki) was that they remain simply "good acquaintances." Mary decided to stay in the Nihongo House for another semester, hoping that she would have Aki as her roommate again. It turned out, however, that Aki decided to leave the house in the following semester. In this respect, Mary's case shows a contrastive example to Ann's. Mary was given access to resources through her Japanese roommate who took up the leadership role in the house, whereas Ann was not. The next case, Sue, reveals yet another type of social experience.

\section{Sue's Case}

Sue is an exchange student from an East Asian country. Her initial motivation for living in the Nihongo House was to interact with Japanese students, using Japanese on a daily basis. She had the best command of Japanese among the three focal cases. However, her English ability was markedly lower than the other two. It was her perceived lack of English ability that made her sign up for the Nihongo House. She repeatedly stated that she did not feel comfortable speaking English and that communication in Japanese was easier for her.

I am not good at English, so all my courses in the fall semester were Japanese language. But, because of that, I was surrounded all by international students, and I had little chance to meet Japanese students. [Sue, Interview on $1 / 24 / 2017$, original in Japanese]

I am bad at English, so native English speakers and those who are good at English, I have a fear toward European people, I think. [Sue, Interview on $1 / 24 / 2017$, original in Japanese]

In a way, this is an ironic statement for someone studying in an EMI program. Nonetheless, as it seems, the Nihongo House is deemed as a solution to Sue's problem-trying to meet Japanese students while avoiding speaking English. Correspondingly, Sue's personal network shows a unique configuration of her interpersonal relationships (Figure 10). Similar to Mary, Sue's prominence in the house was markedly low in the beginning. She only had limited connections with the housemates. 


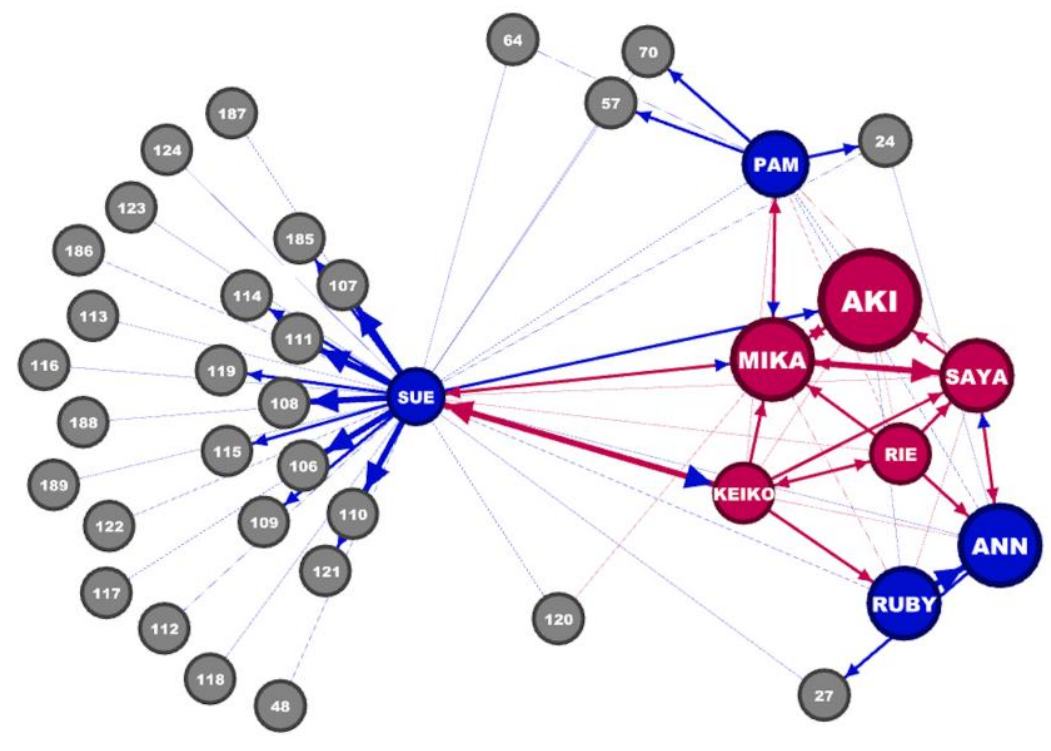

Nonetheless, Sue had many links with people outside of the house. Part of these connections were her compatriot friends with whom she shares her native language, and therefore, with whom she can supposedly communicate with ease. Additionally, due partly to her lack of English command, Sue apparently felt more comfortable with Asian students than others.

In the beginning, (they are) of the same Asian descent, and they are nice. As for other people, everyone speaks English naturally, and as I am bad at English, I try to speak with everyone in Japanese, but because we are of the same Asian descent, I can feel safer with them. [Sue, Interview on $1 / 24 / 2017$, original in Japanese]

Among her connections outside the house were the members of the school festival committee that she was part of. In this group she got acquainted with many Japanese students, which is reflected in the abundance of her outside connections.

There was no club I was interested in joining, and I thought I might be able to get to meet Japanese people through planning events on the school festival committee. And I'm also interested in planning events like 
that, so I joined the committee. I'm glad that I did. [Sue, Interview on $1 / 24 / 2017$, original in Japanese]

Sue's roommate was Keiko, and her relationship with Keiko was positive as well. She noted that they would talk about various topics, which helped them become good friends.

Because I am living with my roommate, Keiko, if any of us has some troubling issues or concerns, we share and talk about them, and we become closer. We talked a lot. [Sue, Interview on $1 / 24 / 2017$, original in Japanese]

While Sue maintained good terms with her roommate, she did not pick Keiko to be the closest in the house; instead, she picked Aki. Sue and Aki were taking the same class (i.e., Cross-Cultural Understanding), which apparently brought them closer beyond their interaction in the house. With the increased intimacy with Aki, Sue also gained prominence in the house, as is shown in her personal network at the semester's end (Figure 11). Sue made more connections with the housemates than in the beginning-particularly with non-Asian residents in the house-and her in-degree prominence became one of the highest in the house.

FIGURE 11. SUE'S EGOCENTRIC NETWORK IN THE SEMESTER END

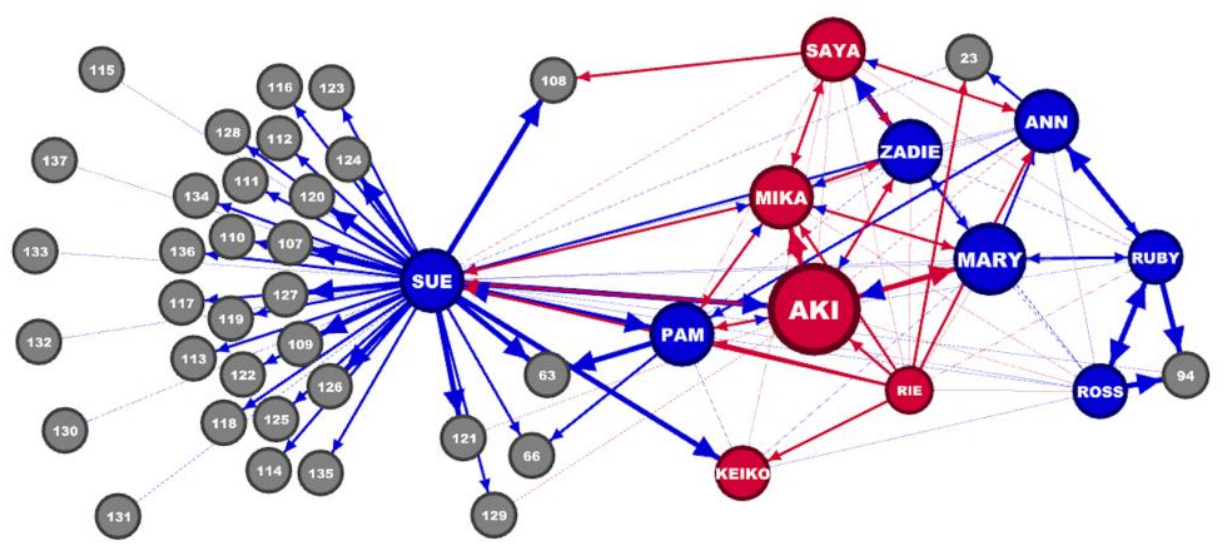

Sue's case is distinct from the first two cases (Ann and Mary) in that she had many active and unique connections outside the house based on her ethnic affiliation and her student organization activities. Note that both groups that she 
belongs to outside the house are non-English speaking groups, with which she feels more comfortable because she does not need to rely on English. Because this is an EMI campus, she is inevitably exposed to English speaking activities. It seems that her active selection of extracurricular activities has been consistent in this regard; that is, motivated by avoidance of English. Moreover, she developed a close relationship with Aki, who was purportedly instrumental in bringing up Sue's prominence among the house members, which is analogous to Mary's case. In this regard, Sue's case illuminates the multitude of overlapping social entities and how belonging to multiple groups may shape their experiences as a whole.

\section{Discussion}

This study took up the institutional unit of Nihongo House and examined how social experiences of the residents were shaped. As a way to look into the structural aspect of interpersonal relationships, we conducted SNA in the beginning and the end of the semester. We identified multiple platforms or loci where relationships were formed and nurtured in the house. These different opportunities can be captured in terms of different degrees of institutionality, or what is official and arranged vs. what is not. First, the roommate matching was the most central institutional arrangement that led to the development of relationships in the house. It was hence a strong indicator of success or failure of social experience at the house for many residents. For example, Ann recounted her experience more or less negatively because of her antagonistic relationship with Rie. Ann did not get the opportunity of daily interaction with Rie due to the unfortunate matching. On the contrary, Mary became close with her roommate, Aki, which made her decide to stay in the Nihongo House in the following semester. Moreover, Mary-who considered herself more or less introverted-was able to expand her social circle towards the end of the semester, seemingly owing to her close relationship with Aki, who played the central role in the house.

While the institutional arrangement of roommate matching so permeated the residents' lives, it does not mean that their relationships were formed solely through such a setup. The residents also nurtured their relationships out of their own volition according to their shared interests and circumstances. This propensity in human relationships is called 'homophily principle' in SNA (McPherson, Smith-Lovin, \& Cook, 2001). As McPherson et al. explained, homophily is omnipresent in any type of relationship, including not only friendship and marriage but also advice and support relationships. For example, Ann became friends with Saya because they shared some commonalities such as being vegetarian, knitting, and so forth. These connections based on personal liking, or McPherson et al. called "value 
homophily" (p. 428), are a strong indicator of social influence within the network, including language use. It is indeed this type of relationship-largely formed on a one-on-one basis-that we often envisage for SA participants (e.g., Diao, 2016). However, such personal connections based on sheer commonality were surprisingly rare in this house. A similar trend has been reported with the case of U.S. universities (e.g., Geary, 2016). Thus, in order for spontaneous exchanges and friendship to emerge, some (but not too much) institutional intervention may be necessary.

Regarding this last point, the presence of the kotatsu lounge in the Nihongo House is worth elaboration. Spending time together regularly in a loosely bound group setting in the lounge was found to be significant in terms of network formation at the house. In this regard, the kotatsu lounge served as somewhere between institutional and private sphere. On the one hand, the lounge was an institutional space intended to promote interaction among the residents. As such, it served the very purpose of the house. On the other hand, unlike the official activities, such as the weekly meetings and the excursions, lounge gathering was not designated as a required official activity of the house; therefore, whether to join in the lounge or not was left totally up to the discretion of individual residents. Therefore, in a sense, similar-minded people gathered and formed a group in the lounge. For those who frequented the space, this loosely bound, semi-institutional platform apparently served greatly in developing personal connections, and those who did not take advantage of it apparently regretted the loss of opportunities.

It should be noted that through the formation of this loose group, Aki and Mika, who were committed to keeping the social order of the space, often led the conversation in Japanese. Aki and Mika became spontaneous leaders, but the other Japanese students did not take part in this group (except for Saya). Here, different reasons and motivation of the Japanese residents for living in the Nihongo House affected their behavior. Some domestic students, such as Saya and Rie, indicated that their reasons to live in the house were to mingle with international students. Evidently, these students had little chance to interact with international students on a daily basis despite the large number of international students on campus. Aki and Mika, on the other hand, were interested in Japanese language education and in helping students learn Japanese. In this regard, their leadership in the house can be accounted for by their own motivational orientations. Looking this way, the Japanese leaders assumed the role of service provider while the international students who frequented the lounge were the beneficiary of the service. This uneven role distribution, however, was apparently contested by some students, such as Ann, who shied away from the lounge. 
In addition to the benefits and detriments of the lounge space as perceived by the residents, the varied degrees of participation among the residents were also attributable to the consequence of accessibility. For instance, language ability made it difficult for some people to dive into the group where speaking Japanese was the expected norm. Aki recounted that those who were weak in Japanese speaking tended to shy away from the lounge conversations due to their perceived inability. She listed Ruby and Ann, in particular, as examples of such students. Thus, one of the elements that hinders the formation of relationships in this house was the insufficient level of Japanese ability. This is ironic because the very purpose of this themed house was to provide a place for international students to use and improve their Japanese. From the opposite perspective, students' differing English abilities also influenced their connections among international students and contributed to division in the house. Sue's case vividly underscores this aspect. She wanted to avoid English speakers in the house because of her perceived lack of English ability. This also highlights the irony of an EMI where English is the official language, but for some students, the Nihongo House (along with other Japanese dominant groups) served as a safe place.

In addition to language ability, knowing the leader figures-hence, relational configurations and resulting resource flows-made it easier for some students to join the lounge group than others. In this respect, the two central players, Aki and Mika, among others, served as gatekeepers to the lounge group, and their roommates and classmates-including Mary and Sue-seemingly benefitted from knowing them. Our analysis of network demonstrated visually how such influences were socially channeled. One element that was not sufficiently addressed in prior research was the presence of overlaying networks that each individual is part of (Kinginger, 2009). We often tend to look at the community in question-be it classroom, workplace, or even a so-called community of practice (Lave \& Wegner, 1991) - almost in isolation and neglect the presence of other social activities and networks that may well be influential in one's life (Coleman, 2013). These other networks, most notably shown with Ken's case in this study, take up different weights and spaces of his/her daily activities and inevitably affect the relative significance of the Nihongo House network. International exchange students, who tend to be on campus for a shorter period of time, are restricted in this regard. Their social circles are often either residential or class related (Diao, 2016). Sue's connections were notably more elaborate than other international students in this house because she participated in the network of compatriots and that of the school festival committee, in addition to the Nihongo House. These aspects of socialization should be further investigated in future research. 
Our analysis of network formation at the Nihongo House suggests the importance of careful environmental design-both physical space and programming of activities - to maximize the potentials for interaction among residents. It is obviously crucial to create a physical space that facilitates mobility. The apartment-style building used for the Nihongo House apparently constrained exchanges among the residents. Although the kotatsu lounge was aimed to compensate the preexisting architectural problem, it served its purpose only for some limited individuals but not others. In order to make the most out of such a communal space, we believe that the following two points should be considered. First, a communal space should have diverse functions that can cater to various needs and abilities of residents. As it stands now, the kotatsu lounge attracted only those who are equipped with functional Japanese ability because the conversation was led mostly in Japanese. Although the use of Japanese was the raison d'être of the Nihongo House, diverse interactional practices may be strategically introduced to these students to help accommodate their needs and abilities better. For example, there is much to learn from emerging research on translanguaging (e.g., Li, 2017), which may liberate residents from sticking with the monolingual practice. The second element of consideration includes the deconstruction of presumed roles between Japanese and international students. The Japanese residents often assumed the role of provider and the international students took the role of beneficiary in the lounge, which is probably a popular assumption held by most of the residents in the house. These uneven and fixed role assumptions may consequently narrow opportunities for international students to take part in various forms of interaction. In fact, past research on homestay interaction reported how host families adjusted their interaction due to their assumption of an accommodator role (e.g., Iino, 2006). Conversational topics would also be affected by such assumptions (e.g., Cook, 2006). Therefore, programming that encourages international students to take leadership roles should be carefully designed and implemented.

Finally, as one of the first endeavors to make use of SNA in describing socialization processes in SA (cf., Hasegawa, 2019), this study has shed light on the complex interplays among physical environment, institutional programming, personal orientations, dispositions, and abilities, as well as social positioning in myriad networks. However, this study is limited in terms of the availability of data that directly infer social interaction and language use engaged by the participants. Future research-with a more robust collection of network and interaction data-should examine various other contexts with a similar analytical focus, which will contribute to a fuller and more nuanced understanding of SA socialization processes. 


\section{Acknowledgements}

We thank Gloria Allaire for her careful reading of and insightful comments on an earlier version of this paper.

\section{Author Biographies}

Atsushi Hasegawa is Assistant Professor of Japanese Language and Linguistics in the Department of East Asian Languages and Literatures at the University of Hawaii at Manoa. His research is centered around the application of conversation analysis (CA) and social network analysis (SNA) to investigate the process of second language use and learning in and out of the classroom settings.

Chiharu Shima is Associate Professor of Graduate School of Global Communication and Language at Akita International University in Japan. Her areas of interest include language socialization and intercultural communication at institutional settings, multilingualism, and medical interaction. Her most recent project studies the language socialization processes of internationally educated nurses who relocated to Japan under a program based on an economic partnership agreement.

\section{References}

Allen, H. W. (2010). What shapes short-term study abroad experiences? A comparative case study of students' motives and goals. Journal of Studies in International Education, 14(5), 452-470 .

Allen, H. W., Dristas, V., \& Mills, N. A. (2006). Cultural learning outcomes and summer study abroad. In M. Mantero (Ed.), Identity and second language learning: Culture, inquiry, and dialogic activity in educational contexts (pp. 187-214). Charlotte, NC: Information Age Publishing.

Allen H. W. \& Herron, C. (2003). A mixed-methodology investigation of the linguistic and affective outcomes of summer study abroad. Foreign Language Annals, 36(3), 370385.

Bastian M, Heymann S, Jacomy M (2009). Gephi: an open source software for exploring and manipulating networks. ICWSM. International AAAI Conference on Weblogs and Social Media.

Benson, P., Barkhuizen, G., Bodycott, P., \& Brown, J. (2013). Second language identity in narratives of study abroad. London, UK: Palgrave Macmillan.

Borgatti, S. P., Everett, M. G., \& Johnson, J. C. (2013). Analyzing social networks. Thousand Oaks, CA: Sage.

Campbell, R. (2011). The impact of study abroad on Japanese language learners' social networks. New Voices 5, 25-63.

Campbell, R. (2015). Life post-study abroad for the Japanese language learner: Social networks, interaction and language usage. In R. Mitchell, N. Tracy-Ventura, \& K. McManus (Eds.), EuroSLA monograph series 4: Social interaction, identity and language learning during residence abroad (pp. 241-262). Amsterdam: The European Second Language Association. 
Carrington, P. J. \& Scott, J. (2011). Introduction. In J. Scott \& P. J. Carrington. (Eds.), The SAGE handbook of social network analysis (pp. 1-8). London: SAGE.

Coleman, J. A. (2013). Researching whole people and whole lives. In C. Kinginger (Ed), Social and cultural aspects of language learning in study abroad (pp. 17-44). Amsterdam: John Benjamins.

Coleman, J. A. (2015). Social circles during residence abroad: What students do, and who with. In R. Mitchell, N. Tracy-Ventura, \& K. McManus (Eds.), EuroSLA monograph series 4: Social interaction, identity and language learning during residence abroad (pp. 33-52). Amsterdam: The European Second Language Association.

De Lange, D., Agneessens, F., \& Waege, H. (2004). Asking social network questions: A quality assessment of different measures. Metodoloski Zvezki, 1(2), 351-378.

Dewey, D. P. (2004). A comparison of reading development by learners of Japanese in intensive domestic immersion and study abroad contexts. Studies in Second Language Acquisition, 26, 303-327.

Dewey, D. P., Belnap, R. K., \& Hillstrom, R. (2013). Social network development, language use, and language acquisition during study abroad: Arabic language learners' perspectives. Frontiers: The Interdisciplinary Journal of Study Abroad, 22, 84-110.

Dewey, D. P., Bown, J., \& Eggett, D. (2012). Japanese language proficiency, social networking, and language use during study abroad: Learners' perspectives. Canadian Modern Language Review, 68, 111-137.

Dewey, D. P., Ring, S., Gardner, D., \& Belnap, R. K. (2013). Social network formation and development during study abroad in the Middle East. System: An International Journal of Educational Technology and Applied Linguistics, 41, 269-282.

Duff, P. (2007). Second language socialization as sociocultural theory: Insights and issues. Language Teaching, 40, 309-319.

Duff, P. A., \& Talmy, S. (2011). Language socialization approaches to second language acquisition. In D. Atkinson (Ed.), Alternative approaches to second language acquisition (pp. 95-116). New York: Routledge.

Freed, B. (Ed.). (1995). Second language acquisition in a study abroad context. Amsterdam: John Benjamins.

Freed, B., Segalowitz, N., \& Dewey, D. (2004). Context of learning and second language fluency in French: Comparing regular classroom, study abroad, and intensive domestic immersion programs. Studies in Second Language Acquisition, 26(2), 275301.

Geary, D. (2016). How Do We Get People to Interact? International Students and the American Experience. Journal of International Students, 6(2), 527-541. Retrieved from https://www.ojed.org/index.php/jis/article/view/369

Hasegawa, A. (2019). The social lives of study abroad: Understanding second language learners' experiences through social network analysis and conversation analysis. New York: Routledge.

Institute for International Education. (2017). Open doors online: Report on international educational exchange. Retrieved July 20, 2018 from https://www.iie.org/Researchand-Insights/Open-Doors/

Isabelli-García, C. (2006). Study abroad social networks, motivation and attitudes: Implications for second language acquisition. In M. DuFon \& E. Churchill (Eds.), Language learners in study abroad contexts (pp. 231-258). Clevedon: Multilingual Matters.

Isabelli-García, C., Bown, J., Plews, J. L., \& Dewey, D. P. (2018). Language learning and study abroad. Language Teaching, 51(4), 439-484. 
Jackson, J. (2008). Globalization, internationalization, and short-term stays abroad. International Journal of Intercultural Relations, 32, 349-358.

Jackson, J. (2013). Transformation of "a frog in the well": A path to a more intercultural, global mindset. In C. Kinginger (Ed), Social and cultural aspects of language learning in study abroad (pp. 101-125). Amsterdam: John Benjamins.

Jacomy, M., Venturini, T., Heymann, S., \& Bastian, M. (2014). ForceAtlas2, a continuous graph layout algorithm for handy network visualization designed for the Gephi software. PLOS One, 9(6), e98679.

Kedzierski, M. (2016). English as a medium of instruction in East Asia's higher education sector: A critical realist Cultural Political Economy analysis of underlying logics. Comparative Education, 52, 375-391.

Kinginger, C. (2008). Language learning in study abroad: Case studies of Americans in France. The Modern Language Journal Monograph, 92(s1), 1-124.

Kinginger, C. (2009). Language learning and study abroad: A critical reading of research. Basingstoke, UK: Palgrave Macmillan.

Kinginger, C. (Ed.). (2013). Social and cultural aspects of language learning in study abroad. Amsterdam: John Benjamins.

Kirkpatrick, A. (2011). The language(s) of HE: EMI and/or ELF and/or multilingualism? The Asian Journal of Applied Linguistics, 1(1), 4-15.

Kramsch, C., \& Steffensen, S. V. (2008). Ecological perspectives on second language acquisition and socialization. In P. Duff \& N. Hornberger (Eds.), Encyclopedia of language and education. Vol.8: Language socialization (pp. 17-28). New York: Springer.

Kurata, N. (2011). Foreign language learning and use: Interaction in informal social networks. London: Continuum.

Lafford, B. A. (1995). Getting into, through and out of a survival situation: A comparison communicative strategies used by students studying Spanish abroad and 'at home.' In B. Freed (Ed.), Second language acquisition in a study abroad context (pp. 97-121). Philadelphia, John Benjamins.

Lave, J. \& E. Wenger. (1991). Situated learning: Legitimate peripheral participation. New York: Cambridge University Press.

Leong, P. NG C. (2017). English-medium instruction in Japanese universities: Policy implementation and constraints. Current Issues in Language Planning, 18(1), 57-67.

Li, W. (2017). Translanguaging as a practical theory of language. Applied Linguistics, 39(1), 9-30.

Macaro, E., Curle, S., Pun, J., An, J., \& Dearden, J. (2018). A systematic review of English medium instruction in higher education. Language Teaching, 51(1), 36-76.

Magnan, S. S. \& Back, M. (2007). Social interaction and linguistic gain during study abroad. Foreign Language Annals, 40(1), 43-61.

Matsunaga, Y. (2012). Learner investment, identity, and imagined communities: A study of Japanese Language House community (Doctoral Dissertation). Retrieved from ProQuest. (UMI Number: 3512833)

McPherson, M., Smith-Lovin, L., \& Cook, J. M. (2001). Birds of a feather: Homophily in social networks. Annual Review of Sociology, 27, 415-444.

Oxford University. (2017). International trends in higher education 2016-2017. Retrieved from http://www.ox.ac.uk/sites/files/oxford/trends\%20in\%20globalisation_WEB.pdf.

Plews, J. L., \& Jackson, J. (Eds.). (2017). Study Abroad to, from, and within Asia. Special issue of Study Abroad Research in Second Language Acquisition and International Education 2(2). Amsterdam: John Benjamins. 
Romney, A. K. \& Weller, S. C. (1984). Predicting informant accuracy from patterns of recall among individuals. Social Network, 6, 59-77.

Sanz, C. \& Morales-Front, A. (Eds.). (2018). The Routledge handbook of study abroad research and practice. New York, NY: Routledge.

Schieffelin, B. B. \& Ochs, E. (1986). Language socialization across cultures. New York: Cambridge University Press.

Segalowitz, N. \& Freed, B. (2004). Context, contact, and cognition in oral fluency acquisition: Learning Spanish in at home and study abroad contexts. Studies in Second Language Acquisition, 26(2), 173-199.

Taguchi, N. (2014). Development of interactional competence in Japanese as a second language: Use of incomplete sentences as interactional resources. The Modern Language Journal, 98, 518-535.

Taguchi, N. (2015). Developing interactional competence in a Japanese study abroad context. Bristol/New York: Multilingual Matters.

Trentman, E. (2013). Arabic and English during study abroad in Cairo, Egypt: Issues of access and use. The Modern Language Journal, 97(2), 457-473.

Umino, T., \& Benson, P. (2016). Communities of practice in study abroad: A four-year study of an Indonesian student's experience in Japan. The Modern Language Journal, 100(4), 757-774.

Walkinshaw, I., Fenton-Smith, B., \& Humphreys, P. (2017). EMI issues and challenges in AsiaPacific higher education: An introduction. In B. Fenton-Smith, P. Humphreys, \& I. Walkinshaw (Eds.), English medium instruction in higher education in Asia-Pacific: from policy to pedagogy (pp. 1-18). Cham, Switzerland: Springer.

Wolcott, T. (2016). Introduction to the special issue: Study abroad in the twenty-first century. L2 Journal, 8(2), 3-11.

Zappa-Hollman, S. \& Duff, P. (2015). Academic English socialization through individual networks of practice. TESOL Quarterly, 49(2), 333-368.

\section{Appendix: Social Network Survey}

(A) Name (first) (last)

(B) Email:

(C) Explain the reasons why you decided to live in Nihongo house.

(D) Name one person (Japanese or international student) with whom you have developed the closest relationship at Japanese University so far. Explain how you became close to this person.

(E) Name one person (Japanese or international student) with whom you have developed the closest relationship in Nihongo house so far. Explain how you became close to this person.

(F) What do you expect from Nihongo house? Explain your thoughts freely on the following items:

(G) For each individual below, evaluate your relationship with them on the following elements. 
(a) Do you consider this person as a friend (i.e., someone you hang out with in your spare time)?

(b) How close do you feel to this person?

(c) In the past few weeks, how often did you interact with this person outside the classroom?

Please know that your response is completely confidential. No one but the researchers will know how you answered this questionnaire.

\begin{tabular}{|c|c|c|c|}
\hline NAME & $\begin{array}{l}\text { Do you consider this } \\
\text { person as a friend } \\
\text { (someone you hang } \\
\text { out with in your spare } \\
\text { time)? }\end{array}$ & $\begin{array}{c}\text { How close do you feel } \\
\text { to this person? }\end{array}$ & $\begin{array}{l}\text { In the past few weeks, } \\
\text { how often did you } \\
\text { interact with this } \\
\text { person outside the } \\
\text { classroom? }\end{array}$ \\
\hline Resident 1 & $\begin{array}{l}\text { ( ) Yes } \\
\text { ( ) No }\end{array}$ & $\begin{array}{l}\text { ( ) Very close } \\
\text { ( ) Close } \\
\text { ( ) Less than close } \\
\text { ( ) Distant }\end{array}$ & $\begin{array}{l}\text { ( ) Every day } \\
\text { ( ) Multiple times a } \\
\text { week } \\
\text { ( ) Once or twice a } \\
\text { week } \\
\text { ( ) Less/Never }\end{array}$ \\
\hline Resident 2 & $\begin{array}{l}\text { ( ) Yes } \\
\text { ( ) No }\end{array}$ & $\begin{array}{l}\text { ( ) Very close } \\
\text { ( ) Close } \\
\text { ( ) Less than close } \\
\text { ( ) Distant }\end{array}$ & $\begin{array}{l}\text { ( ) Every day } \\
\text { ( ) Multiple times a } \\
\text { week } \\
\text { ( ) Once or twice a } \\
\text { week } \\
\text { ( ) Less/Never }\end{array}$ \\
\hline Resident 3 & $\begin{array}{l}\text { ( ) Yes } \\
\text { ( ) No }\end{array}$ & $\begin{array}{l}\text { ( ) Very close } \\
\text { ( ) Close } \\
\text { ( ) Less than close } \\
\text { ( ) Distant }\end{array}$ & $\begin{array}{l}\text { ( ) Every day } \\
\text { ( ) Multiple times a } \\
\text { week } \\
\text { ( ) Once or twice a } \\
\text { week } \\
\text { ( ) Less/Never }\end{array}$ \\
\hline Resident 4 & $\begin{array}{l}\text { ( ) Yes } \\
\text { ( ) No }\end{array}$ & $\begin{array}{l}\text { ( ) Very close } \\
\text { ( ) Close } \\
\text { ( ) Less than close } \\
\text { ( ) Distant }\end{array}$ & $\begin{array}{l}\text { ( ) Every day } \\
\text { ( ) Multiple times a } \\
\text { week } \\
\text { ( ) Once or twice a } \\
\text { week } \\
\text { ( ) Less/Never }\end{array}$ \\
\hline Resident 5 & $\begin{array}{l}\text { ( ) Yes } \\
\text { ( ) No }\end{array}$ & $\begin{array}{l}\text { ( ) Very close } \\
\text { ( ) Close } \\
\text { ( ) Less than close } \\
\text { ( ) Distant }\end{array}$ & $\begin{array}{l}\text { ( ) Every day } \\
\text { ( ) Multiple times a } \\
\text { week } \\
\text { ( ) Once or twice a } \\
\text { week } \\
\text { ( ) Less/Never }\end{array}$ \\
\hline Resident 6 & $\begin{array}{l}\text { ( ) Yes } \\
\text { ( ) No }\end{array}$ & $\begin{array}{l}\text { ( ) Very close } \\
\text { ( ) Close } \\
\text { ( ) Less than close } \\
\text { ( ) Distant }\end{array}$ & $\begin{array}{l}\text { ( ) Every day } \\
\text { ( ) Multiple times a } \\
\text { week } \\
\text { ( ) Once or twice a } \\
\text { week } \\
\text { ( ) Less/Never }\end{array}$ \\
\hline
\end{tabular}




\begin{tabular}{|c|c|c|c|}
\hline Resident 7 & $\begin{array}{l}\text { ( ) Yes } \\
\text { ( ) No }\end{array}$ & $\begin{array}{l}\text { ( ) Very close } \\
\text { ( ) Close } \\
\text { ( ) Less than close } \\
\text { ( ) Distant }\end{array}$ & $\begin{array}{l}\text { ( ) Every day } \\
\text { ( ) Multiple times a } \\
\text { week } \\
\text { ( ) Once or twice a } \\
\text { week } \\
\text { ( ) Less/Never }\end{array}$ \\
\hline Resident 8 & $\begin{array}{l}\text { ( ) Yes } \\
\text { ( ) No }\end{array}$ & $\begin{array}{l}\text { ( ) Very close } \\
\text { ( ) Close } \\
\text { ( ) Less than close } \\
\text { ( ) Distant }\end{array}$ & $\begin{array}{l}\text { ( ) Every day } \\
\text { ( ) Multiple times a } \\
\text { week } \\
\text { ( ) Once or twice a } \\
\text { week } \\
\text { ( ) Less/Never }\end{array}$ \\
\hline Resident 9 & $\begin{array}{l}\text { ( ) Yes } \\
\text { ( ) No }\end{array}$ & $\begin{array}{l}\text { ( ) Very close } \\
\text { ( ) Close } \\
\text { ( ) Less than close } \\
\text { ( ) Distant }\end{array}$ & $\begin{array}{l}\text { ( ) Every day } \\
\text { ( ) Multiple times a } \\
\text { week } \\
\text { ( ) Once or twice a } \\
\text { week } \\
\text { ( ) Less/Never }\end{array}$ \\
\hline Resident 10 & $\begin{array}{l}\text { ( ) Yes } \\
\text { ( ) No }\end{array}$ & $\begin{array}{l}\text { ( ) Very close } \\
\text { ( ) Close } \\
\text { ( ) Less than close } \\
\text { ( ) Distant }\end{array}$ & $\begin{array}{l}\text { ( ) Every day } \\
\text { ( ) Multiple times a } \\
\text { week } \\
\text { ( ) Once or twice a } \\
\text { week } \\
\text { ( ) Less/Never }\end{array}$ \\
\hline
\end{tabular}

(H) List all other people with whom you interacted in the past few weeks (e.g., classmates, members of clubs/circles, friend's friends, etc.) and evaluate your relationships with them in the same way.

\begin{tabular}{|c|c|c|c|}
\hline $\begin{array}{l}\text { NAME } \\
\text { (description } \\
\text { of } \\
\text { relationship) }\end{array}$ & $\begin{array}{l}\text { Do you consider this } \\
\text { person as a friend } \\
\text { (someone you hang } \\
\text { out with in your spare } \\
\text { time? }\end{array}$ & $\begin{array}{l}\text { How close do you feel } \\
\text { to this person? }\end{array}$ & $\begin{array}{l}\text { In the past few weeks, } \\
\text { how often did you } \\
\text { interact with this } \\
\text { person outside the } \\
\text { classroom? }\end{array}$ \\
\hline \multirow[t]{3}{*}{$\begin{array}{c}\text { Ichiro } \\
\text { Suzuki } \\
\text { (tennis club) }\end{array}$} & $\begin{array}{l}(\checkmark) \text { Yes } \\
(\text { ) No }\end{array}$ & $\begin{array}{l}\text { ( ) Very close } \\
\text { ( }) \text { Close } \\
\text { ( ) Less than close } \\
\text { ( ) Distant }\end{array}$ & $\begin{array}{l}\text { ( ) Every day } \\
\text { ( ) Multiple times a } \\
\text { week } \\
\text { ( }) \text { Once or twice a } \\
\text { week } \\
(\quad \text { ) Less/Never }\end{array}$ \\
\hline & $\begin{array}{l}\text { ( ) Yes } \\
\text { ( ) No }\end{array}$ & $\begin{array}{l}\text { ( ) Very close } \\
\text { ( ) Close } \\
\text { ( ) Less than close } \\
\text { ( ) Distant }\end{array}$ & $\begin{array}{l}\text { ( ) Every day } \\
\text { ( ) Multiple times a } \\
\text { week } \\
\text { ( ) Once or twice a } \\
\text { week } \\
\text { ( ) Less/Never }\end{array}$ \\
\hline & $\begin{array}{l}\text { ( ) Yes } \\
\text { ( ) No }\end{array}$ & $\begin{array}{l}\text { ( ) Very close } \\
\text { ( ) Close }\end{array}$ & ( ) Every day \\
\hline
\end{tabular}




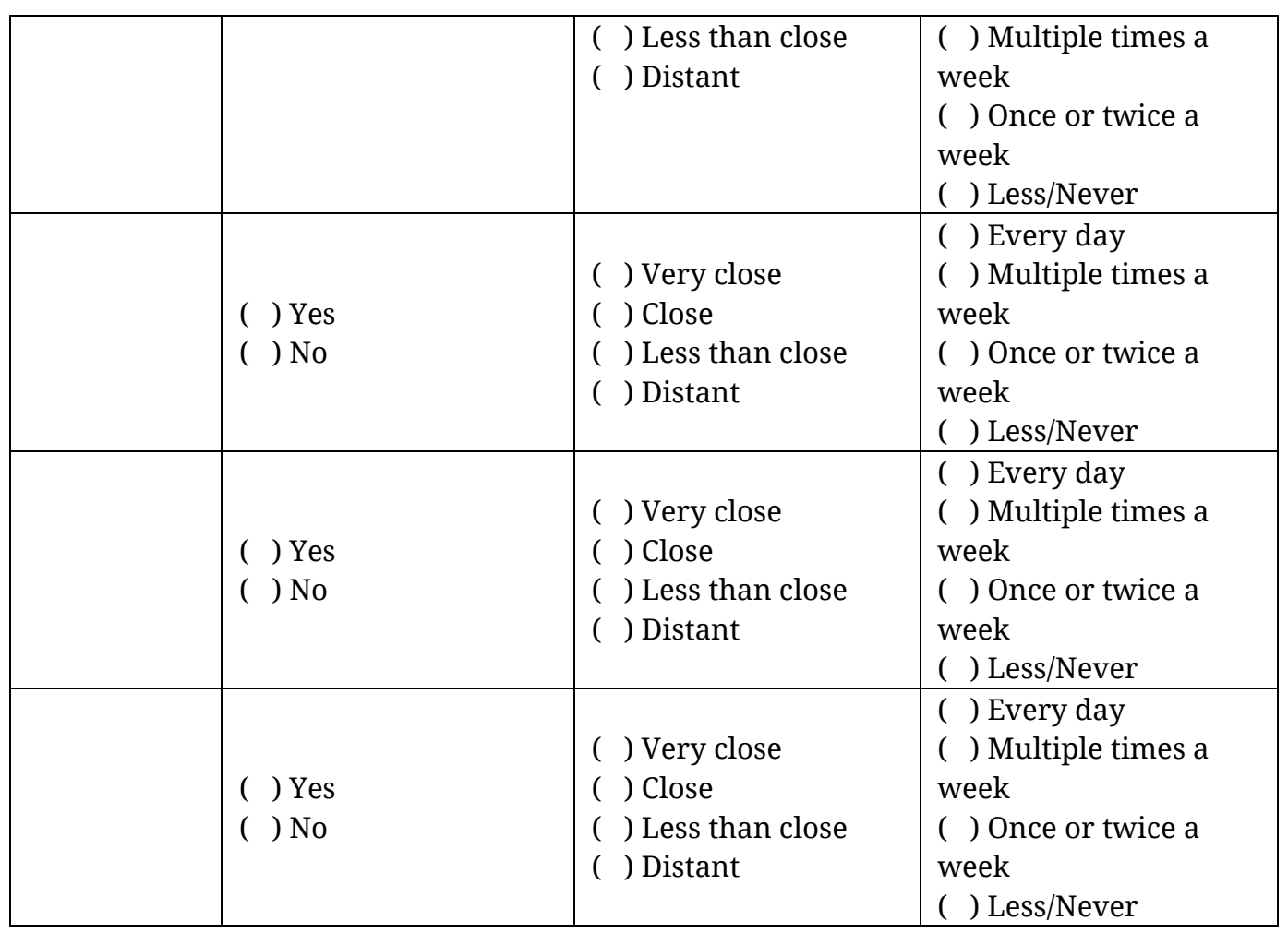

